\title{
Handbook of
}

\section{Experimental Pharmacology}

\section{Volume 108/II}

Editorial Board

G.V.R. Born, London

P. Cuatrecasas, Ann Arbor, MI

H. Herken, Berlin

K. Melmon, Stanford, CA 


\section{GTPases in Biology II}

Contributors

M. Biel, L. Birnbaumer, K.J. Blumer, J. Bockaert, E. Bosse, J.L. Boyer, P. Brabet, M. Camps, M.G. Caron, P.J. Casey, J. Chen, K. Clark, D. Corda, S. Coulter, P.N. Devreotes, D. Donelly, T.D. DuBose, Jr., J.H. Exton, J.B.C. Findlay, R.A. Firtel, V. Flockerzi, M. Forte, C. Gaskins, P. Gierschik, R. Gundersen, R.W. Gurich, J.R. Hadcock, J.A. Hadwiger, T.K. Harden, J.D. Hildebrandt, Y.-K. Ho, F. Hofmann, K.P. Hofmann, V. Homburger, M.D. Houslay, R. Hullin, D. Hyde, R. Iyengar, O. Jacobowitz, S. Jahangeer, K.H. Jakobs, G.L. Johnson, R.L. Johnson, N. Kimura, S.D. Kroll, Y. Kurachi, R.H. Lee, R.J. Lefkowitz, Y. Li, C. Londos, C.C. Malbon, D.H. Maurice, K.R. McLeish, G. Milligan, A.J. Morris, E.J. Neer, A.S. Otero, U. Panten, D. Park, G.S. Pitt, R.T. Premont, F. Quan, M. Rodbell, W. Rosenthal, M. Russell, P. Ruth, C. Schwanstecher, M. Schwanstecher, I.A. Simpson, E. Stefani, G. Szabo, J.A. Thissen, T.D. Ting, L. Toro, G.L. Waldo, A. Welling, T.G. Wensel, M. Whiteway, W. Wolfgang, L. Wu

\section{Editors}

Burton F. Dickey and Lutz Birnbaumer

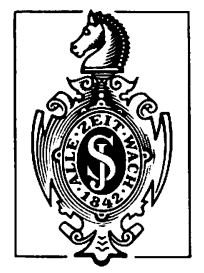

Springer-Verlag

Berlin Heidelberg New York London Paris Tokyo Hong Kong Barcelona Budapest 


\section{Contents}

Section IV: Signal Transduction by Trimeric G Proteins

A. Cellular Architecture and its Role in Signal Transduction

CHAPTER 44

G-Proteins Have Properties of Multimeric Proteins: An Explanation for the Role of GTPases in their Dynamic Behavior

M. Rodbell, S. Jahangeer, and S. Coulter. With 2 Figures ...... 3

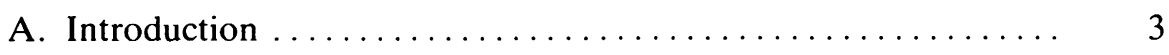

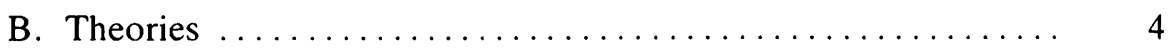

I. Shuttle Theory ............................ 4

II. Collision-coupling Theory $\ldots \ldots \ldots \ldots \ldots \ldots \ldots \ldots \ldots, 4$

III. Disaggregation Theory ...................... 5

C. Evidence for Multimeric Structures of G-Proteins ........... 5

I. Properties in Detergents ..................... 5

II. Cross-Linking of G-Proteins in Membranes ........... 6

III. Glucagon Activation of Multimeric $\mathrm{G}_{\mathrm{s}}$ in Hepatic Membranes.............................. 7

D. Coupling of Receptors to Multimeric G-Proteins .......... 8

E. Hydrolysis of GTP Is Fundamental to Signal Transduction

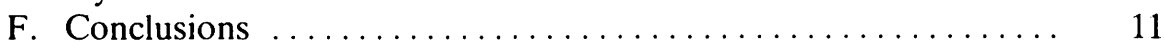

References................................ 12

B. G-Protein Coupled Receptors

CHAPTER 45

The Superfamily: Molecular Modelling

J.B.C. Findlay and D. Donnelly. With 4 Figures ........... 17

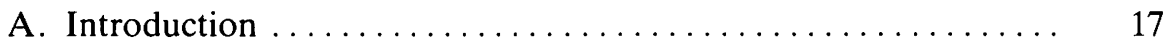

B. General Principles - Modelling Integral Membrane Domains .... 18 
CHAPTER 50

The GTPase Cycle: Transducin

T.D. Ting, R.H. LeE, and Y.-K. Ho. With 6 Figures . . . . . . . . . 99

A. The Retinal cGMP Cascade and Visual Excitation . . . . . . . . . 99

B. The Coupling Cycle of Transducin . . . . . . . . . . . . . . . . . 100

C. The Reaction Dynamics of the Transducin Cycle . . . . . . . . . . 102

I. Transducin Subunit Interaction . . . . . . . . . . . . . . . 102

II. Pre-Steady-State Kinetic Analysis of the GTP Hydrolysis Reaction ... . . . . . . . . . . . . . . . . . . . . . . . . . . . . 104

III. Quantitative Analysis of the Pre-Steady-State Kinetics . . . . . 107

D. Relationship of GTP Hydrolysis and PDE Deactivation . . . . . . . 110

E. Regulation of the Transducin Coupling Cycle by Phosducin . . . . 113

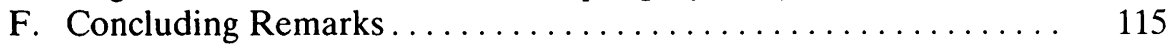

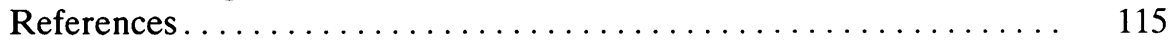

\section{CHAPTER 51}

Transcriptional, Posttranscriptional, and Posttranslational Regulation of G-Proteins and Adrenergic Receptors

J.R. Hadcock and C.C. Malbon. With 2 Figures . . . . . . . . . . . . 119

A. Introduction . . . . . . . . . . . . . . . . . . . . . . 119

B. Agonist-Induced Regulation of Transmembrane Signaling . . . . . 120

I. Transcriptional and Posttranscriptional Regulation ....... 120

II. Posttranslational Regulation .................. 123

C. Cross-Regulation in Transmembrane Signaling . . . . . . . . . . 123

I. Stimulatory to Inhibitory Adenylyl Cyclase . . . . . . . . . . 123

II. Inhibitory to Stimulatory Adenylyl Cyclase . . . . . . . . . . . . . 124

III. Stimulatory Adenylyl Cyclase to Phospholipase C . . . . . . . 125

IV. Tyrosine Kinase to Stimulatory Adenylyl Cyclase . . . . . . . 126

D. Permissive Hormone Regulation of Transmembrane Signaling . . . 126

E. Perspectives ........................... 127

References............................... 128

\section{CHAPTER 52}

G-Protein Subunit Lipidation in Membrane Association and Signaling J.A. Thissen and P.J. Casey. With 4 Figures . . . . . . . . . . 131

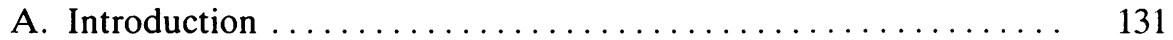

B. Myristoylation and Membrane Association of G-Protein $\alpha$ Subunits ........................... 133

I. Cotranslational Processing of G-Protein $\alpha$ Subunits . . . . . . . 133

II. The Role of Myristoylation in $\alpha$ Subunit-Membrane Association 
C. Prenylation and Membrane Association of G-Protein $\gamma$ Subunits 138

I. Posttranslational Processing of G-Protein $\gamma$ Subunits . . . . . . 138

II. The Role of Prenylation in $\gamma$ Subunit-Membrane Association ........................... 139

1. Geranylgeranyl-Modified $\gamma$ Subunits . . . . . . . . . 140

2. Farnesyl-Modified $\gamma$ Subunits . . . . . . . . . . . . . . . 142

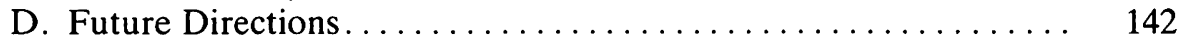

References........................... 143

\section{CHAPTER 53}

Phosphorylation of Heterotrimeric G-Protein

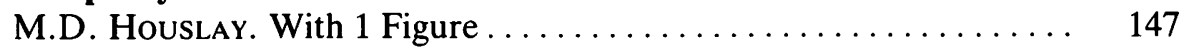

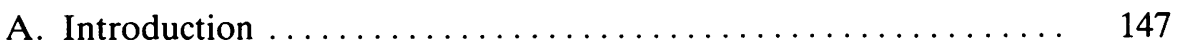

I. Nature of G-Proteins . . . . . . . . . . . . . . . . . 147

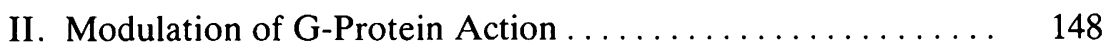

1. Phosphorylation ....................... 149

B. Phosphorylation of Heterotrimeric G-proteins in Intact Cells . . . 150

I. Hepatocytes .......................... 150

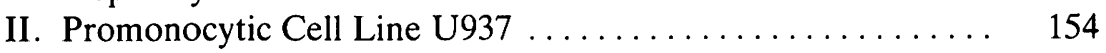

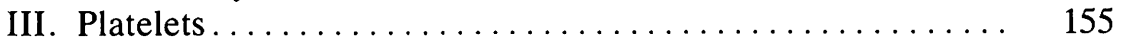

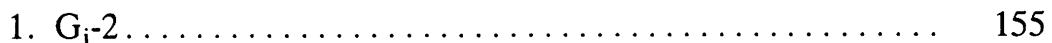

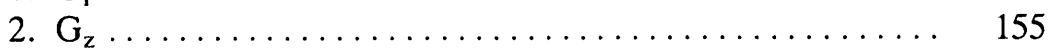

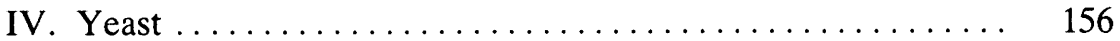

V. Dictyostelium .......................... 157

C. In Vitro Phosphorylation of Isolated Heterotrimeric G-Proteins . . 158

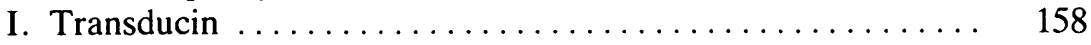

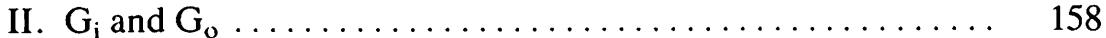

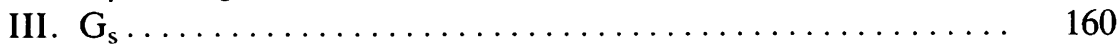

IV. Unidentified "G-Proteins" ...................... 161

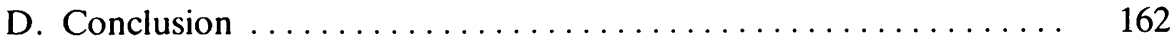

References............................... 162

\section{CHAPTER 54}

Receptor to Effector Signaling Through G-Proteins:

$\beta \gamma$ Dimers Join $\alpha$ Subunits in the World of Higher Eukaryotes

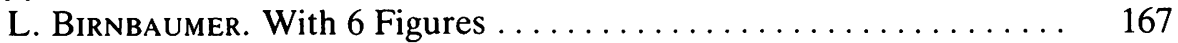

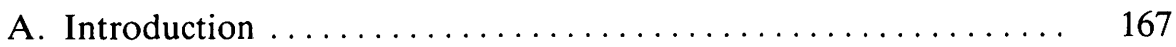

B. $\beta \gamma$ Dimers and Adenylyl Cyclase .................. 168

I. Hormonal Inhibition of Adenylyl Cyclase and Stimulation of $\mathrm{K}^{+}$Channels: Controversies that Settled Mostly in Favor of $\alpha$ Subunits ................................ 168 
II. Conditional and Subtype-Specific Regulation of Adenylyl Cyclase Activity by $\beta \gamma$ Dimers

C. $\beta \gamma$ Dimers and Phospholipase C: Subtype-Specific Stimulation of

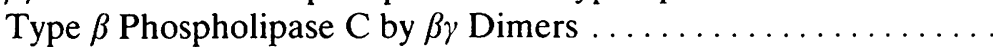

D. $\beta \gamma$ Dimers and Receptors: Exquisite Specificity of Receptors for $\beta \gamma$ Subtypes...

E. Dual Signaling of Single Receptors: Mediation by One or by Two G-Proteins?

I. Inhibition of Adenylyl Cyclase and Stimulation of Phospholipase C.

II. Signaling Quality Through Receptor Quantity?

III. Dual Stimulation of Adenylyl Cyclase and Phospholipase C

IV. Evidence for Physical Interaction of a Single Receptor with Two Distinct Types of G-Proteins. .

F. The Puzzle of the Up-Shifted Dose-Response Curves for Phospholipase C Elicited by Adenylyl Cyclase Stimulating Agonists

G. Concluding Remarks

References.

D. Effectors of G-Proteins

\section{CHAPTER 55}

Molecular Diversity of Mammalian Adenylyl Cyclases:

\section{Functional Consequences}

R.T. Premont, J. Chen, O. Jacobowitz, and R. Iyengar.

With 5 Figures

A. Introduction ............................... 189

B. Stimulation and Inhibition of Adenylyl Cyclases ........... 190

C. Molecular Diversity of Adenylyl Cyclases . . . . . . . . . . . . . . 193

I. Multiple Families of Adenylyl Cyclases . . . . . . . . . . . 193

II. Secondary Structure and Topography .............. 196

III. Putative Catalytic Sites . . . . . . . . . . . . . . . . . . . . . . . 198

IV. Tissue Distribution of the Various Forms ............ 199

D. G-Protein Regulation of Adenylyl Cyclases .............. 201

I. $G_{s}-\alpha$ Regulation .......................... 201

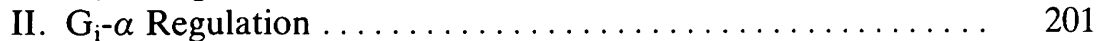

III. $\beta \gamma$ Regulation .......................... 201

E. Type-Specific Regulation by Intracellular Ligands . . . . . . . . 202

I. $\mathrm{Ca}^{2+} / \mathrm{CaM}$ Regulation ..................... 202

II. Inhibition by Low Concentrations of $\mathrm{Ca}^{2+} \ldots \ldots \ldots \ldots \ldots 202$

III. P-Site Inhibition . . . . . . . . . . . . . . . . . . 204 
F. Regulation by Protein Phosphorylation ............... 204

I. Regulation by Protein Kinase C . . . . . . . . . . . . 204

II. Protein Kinase A Regulation: A Component of Heterologous Desensitization ................. 205

G. Functional Consequences of Multiple Adenylyl Cyclases ...... 206

I. Integration of Multiple Signals . . . . . . . . . . . . . 206

II. Modulation of Signal Transmission ............... 207

References.................................... 208

\section{CHAPTER 56}

The Light-Regulated cGMP Phosphodiesterase of Vertebrate Photoreceptors: Structure and Mechanism of Activation by $\mathbf{G}_{\mathbf{t} \alpha}$

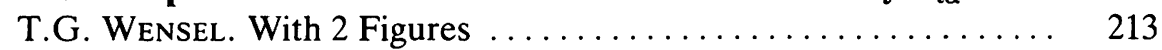

A. Physiological Role of cGMP Phosphodiesterase in Visual

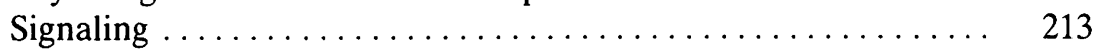

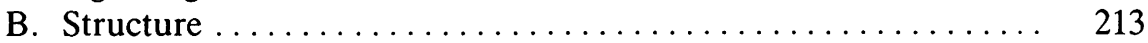

I. Subunit Composition...................... 213

II. Size and Hydrodynamic Properties . . . . . . . . . . . . . 214

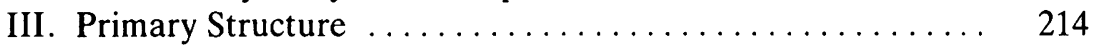

IV. Posttranslational Modifications .................. 214

V. Domain Structures of Subunits ................ 215

1. Catalytic Subunits........................ 215

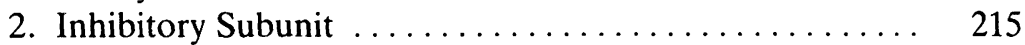

C. Functional Properties ........................ 216

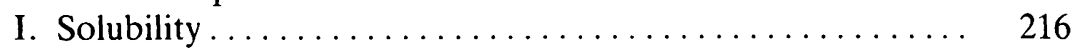

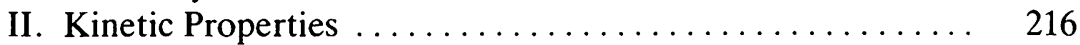

III. Noncatalytic cGMP Binding Sites . . . . . . . . . . 216

D. Regulation of Catalytic Activity ................. 217

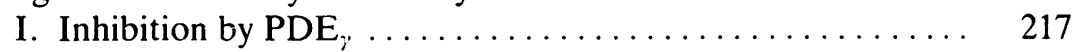

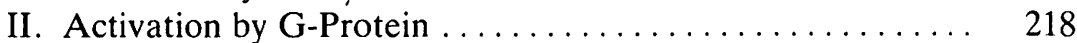

1. Role of $G_{t \alpha} \ldots \ldots \ldots \ldots \ldots \ldots \ldots \ldots \ldots \ldots, 218$

2. Role of Membranes in PDE Activation by $\mathrm{G}_{\mathrm{t} \alpha} \ldots \ldots \ldots 218$

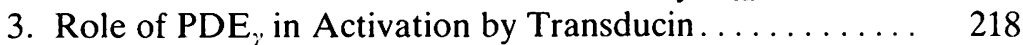

4. Is There Cooperativity in the Action of $G_{1 \alpha}-G T P ? \ldots \ldots 219$

5. A Role for Noncatalytic cGMP Binding Sites? ...... 220

References................................. $\quad 220$

\section{CHAPTER 57}

\section{High-Voltage Activated $\mathrm{Ca}^{2+}$ Channel}

F. Hofmann, M. Biel, E. Bosse, R. Hullin, P. Ruth, A. Wellng, and V. FLocKerZI. With 1 Figure $\ldots \ldots \ldots \ldots \ldots \ldots \ldots \ldots \ldots . \ldots \ldots$

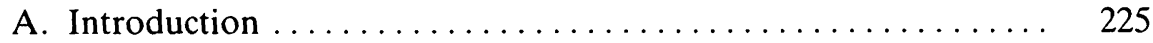


B. Identified cDNAs of High-Voltage Activated

Calcium Channels ............................. 225

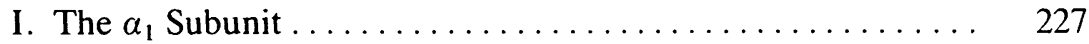

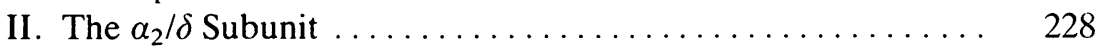

III. The $\beta$ Subunit .............................. 229

IV. The $\gamma$ Subunit ............................. 229

C. Structure-Function of the Cloned Calcium Channel Proteins .... 229

I. Expression and Function of the Channel Subunits ........ 229

II. The Binding Sites for Calcium Channel Blockers ......... 232

III. Phosphorylation of the Channel Proteins ............. 233

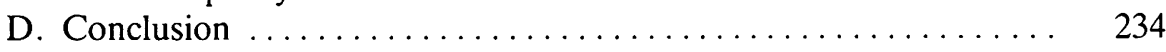

References................................ 234

\section{CHAPTER 58}

Phospholipase C- $\beta$ Isozymes Activated by $\mathbf{G} \alpha_{q}$ Members

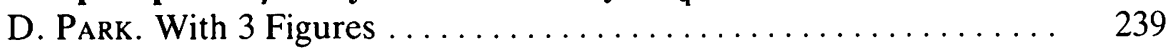

References.................................. 248

\section{CHAPTER 59}

\section{Stimulation of Phospholipase $\mathbf{C}$ by G-Protein $\boldsymbol{\beta} \gamma$ Subunits}

P. GierschiK and M. CAMPS. With 4 Figures ............... 251
A. Introduction
B. Stimulation of Soluble Phospholipase C of HL-60 Granulocytes by G-Protein $\beta \gamma$ Subunits
C. Identification of the $\beta \gamma$-Sensitive Phospholipase C of HL-60

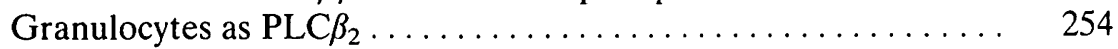
D. Stimulation of PLC $\beta_{2}$ by G-Protein $\beta \gamma$ Subunits in Intact Cells $\ldots 256$
E. Role of $\beta \gamma$ Subunits in Mediating Receptor Stimulation of Phospholipase C
F. Perspectives ................................... 259
References................................. 260

E. Specialized Systems

CHAPTER 60

Rhodopsin/G-Protein Interaction

K.P. Hofmann. With 7 Figures $\ldots \ldots \ldots \ldots \ldots \ldots \ldots \ldots \ldots \ldots \ldots$

A. Introduction ............................... 267

B. Interactions of Rhodopsin in the Visual Cascade .......... 267

C. Biophysical Monitors of G-Protein Activation ............. 270 
I. Description of the Monitors ................... 270

II. Instrumentation ........................ 271

III. Application to the Analysis of $R^{*}-G_{t}$ Interaction . . . . . 273

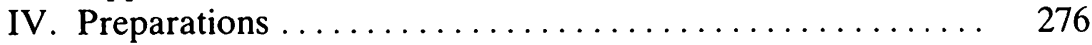

D. Interactive States of Rhodopsin ................... 277

I. Molecular Nature of Metarhodopsin II ............ 277

II. Active Forms of Rhodopsin from Alternative Light-Inuced Pathways ............................... 278

III. Activation of Rhodopsin in the Dark ............. 278

E. Interactive States of Transducin ................... 279

I. Dark Binding ............................ 279

II. Stable Light Binding with Empty Nucleotide Site . . . . . . 279

III. Rhodopsin/G-Protein Interaction with Bound Nucleotles .. 280

F. Mechanism of Transducin Activation ............... 280

I. Role of Rhodopsin's Cytoplasmic Loops .............. 280

1. Three Loops Contribute to MII-G Interaction ....... 280

2. Loop Mutants: Binding and Activation in MII-G $\mathrm{G}_{\mathbf{t}}$ Interaction ............................ 283

II. Dissection of Reaction Steps . . . . . . . . . . . . . . 283

1. The GDP/MII Switch ................... 283

2. The MII/GTP Switch .................... 284

III. Regulation of the Activation Pathway ............ 286

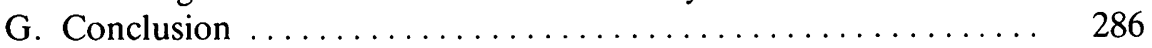

References................................. 287

\section{CHAPTER 61}

\section{Fast Kinetics of G-Protein Function In Vivo}

G. Szabo, Y. Li, and A.S. Otero. With 6 Figures ............ 291

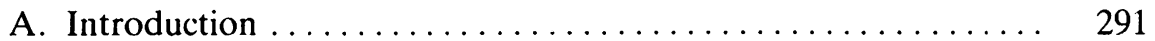

B. Kinetics of Muscarinic $\mathrm{K}^{+}$Channel Activation . . . . . . . . . . 291

C. Rapid Desensitization ............................. 295

D. Kinetics of $I_{K(A C h)}$ Deactivation ................... 298

E. Basic Kinetic Model for Membrane-Delimited Effector

Activation by a G-Protein . . . . . . . . . . . . . . . . . . . 299

F. Conclusions .............................. 300

References.............................. 301

CHAPTER 62

The Yeast Pheromone Response G-Protein

K. Clark and M. Whiteway. With 3 Figures .............. 303

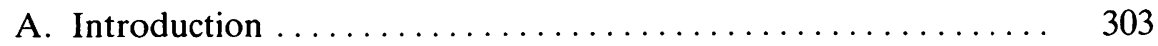

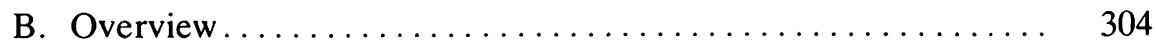


C. Gpa1, the $G \alpha$ Subunit.......................... 305

I. Random Mutagenesis . . . . . . . . . . . . . . . . . 306

II. Site-Directed Mutagenesis . . . . . . . . . . . . . . . . . 307

D. Ste 4 , the $G \beta$ Subunit . . . . . . . . . . . . . . . . . . . 309

I. Random Mutagenesis . . . . . . . . . . . . . . . . . . . . 309

II. Site-Directed Mutagenesis . . . . . . . . . . . . . . . . . . . . 312

E. Ste 18 , the $G \gamma$ Subunit . . . . . . . . . . . . . . . . . . 312

I. Random Mutagenesis . . . . . . . . . . . . . . . . . . 313

II. Site-Directed Mutagenesis . . . . . . . . . . . . . . . . . . . 314

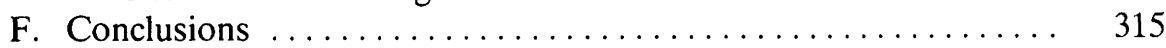

References................................... 315

CHAPTER 63

G $\alpha$ Proteins in Drosophila: Structure and Developmental Expression

M. Forte, F. Quan, D. Hyde, and W. Wolfgang. With 3 Figures. . 319

A. Introduction .................................. 319

I. G-Protein-Coupled Signaling in Development ......... 319

II. The Drosophila System .......................... 319

B. $\mathrm{G} \alpha$-Proteins in Drosophila ...................... $\quad 322$

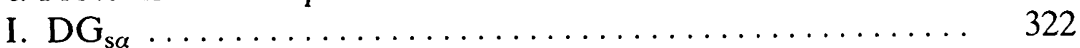

1. Gene Structure ........................ 322

2. Adult and Embryonic Expression .............. 324

3. Stimulation of Mammalian Adenylyl Cyclase Through

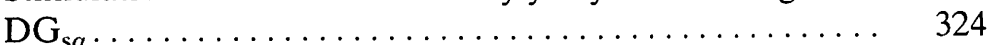

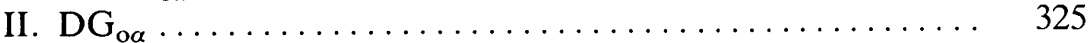

1. Gene Structure ............................ 325

2. Adult and Embryonic Expression . . . . . . . . . . . 325

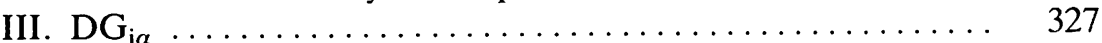

1. Gene Structure ........................... 327

2. Adult and Embryonic Expression . . . . . . . . . . . 327

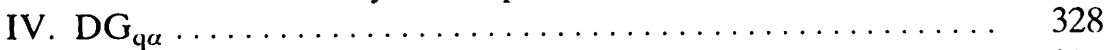

1. Gene Structure ......................... 328

2. Adult Expression ......................... 329

3. Role in Phototransduction .................. 329

V. concertina ................................ 331

1. Mutant Phenotype ...................... 331

2. Cloning and Gene Structure ................ 331

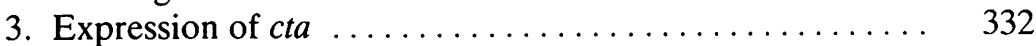

C. Summary ..................................... 332

References.................................... 333

CHAPTER 64

Signal Transduction by G-Proteins in Dictyostelium discoideum

L. Wu, C. Gaskins, R. Gundersen, J.A. Hadwiger, R.L. Johnson, G.S. Pitt, R.A. Firtel, and P.N. Devreotes. With 8 Figures ...... 
A. Introduction .............................. 335

B. Signal Transduction in Dictyostelium ............... 335

C. Diversity of G-Proteins in Dictyostelium ............... 337

D. Roles of G-Proteins in Signal Transduction Processes . . . . . . . $\quad 340$

E. Roles of G-Proteins in Morphogenesis and Differentiation .... 345

F. Conclusions and Perspectives ................... 347

References................................ 348

CHAPTER 65

Functional Expression of Mammalian Receptors and G-Proteins in Yeast

K.J. Blumer. With 1 Figure $\ldots \ldots \ldots \ldots \ldots \ldots \ldots \ldots \ldots \ldots, 351$

A. Introduction ............................. 351

B. Expression of Mammalian G-Protein-Coupled Receptors ..... 352

C. Expression of Mammalian G-Protein Subunits ........... 357

I. Physiological Roles of Yeast G-Protein Subunits . . . . . . . 357

II. Mammalian $\mathrm{G}_{\alpha}$ Subunits $\ldots \ldots \ldots \ldots \ldots \ldots \ldots \ldots \ldots \ldots \ldots$

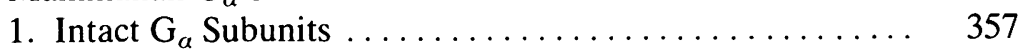

2. Chimeric Yeast/Mammalian $G_{\alpha}$ Subunits......... 358

III. Mammalian $\mathrm{G}_{\beta}$ and $\mathrm{G}_{\text {, }}$ Subunits . .............. 359

D. Signaling Between Mammalian Receptors and G-Proteins ..... $\quad 359$

E. Perspectives .................................. 359

References................................ 360

\section{CHAPTER 66}

G-Proteins in the Signal Transduction of the Neutrophil

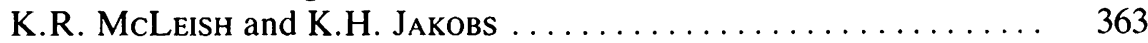

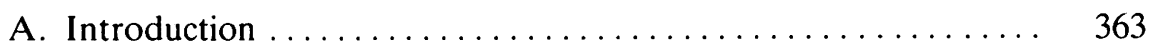

B. Receptor-Mediated PMN Functions . . . . . . . . . . . . 363

I. Adherence ............................ 363

II. Chemotaxis ............................ 364

III. Phagocytosis and Bactericidal Activity . . . . . . . . . 364

IV. Regulatory Receptors ......................... 364

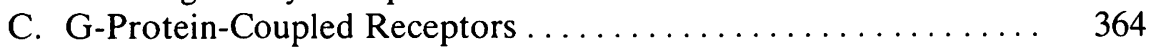

I. Chemoattractant Receptors .................... 365

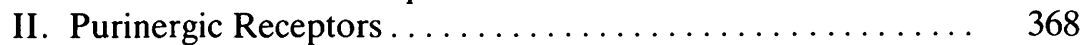

III. Other PMN Receptors . . . . . . . . . . . . . . . . . . . . . 369

D. Regulation of Neutrophil Responses . . . . . . . . . . . . . 369

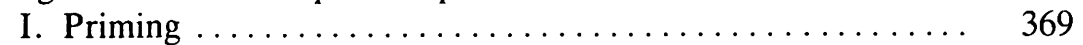

II. Desensitization ........................ 370

References................................ 370 
CHAPTER 67

Hormonal Regulation of Phospholipid Metabolism via G-Proteins:

Phosphoinositide Phospholipase $\mathrm{C}$ and Phosphatidylcholine

\section{Phospholipase D}

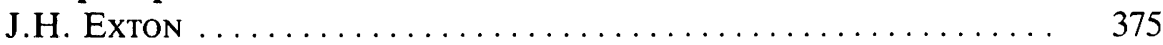

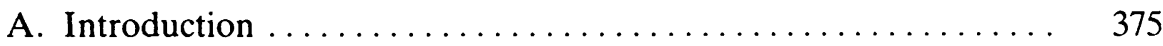

B. Identification of the G-Proteins Regulating PtdInsP $\mathrm{P}_{2}$ Phospholipase C....................... 375

C. Coupling of G-Proteins to $\mathrm{Ca}^{2+}$-Mobilizing Receptors . . . . . . . 377

D. Specificity of Phosphoinositide Phospholipase C Linked to $\mathrm{G}_{\mathrm{q}}$

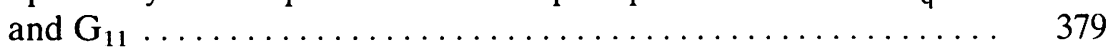

E. Mechanisms of Agonist-Stimulated Phosphatidylcholine

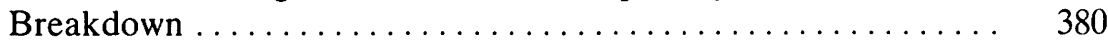

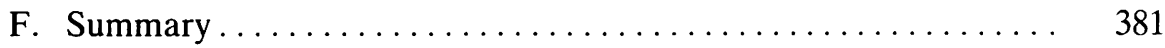

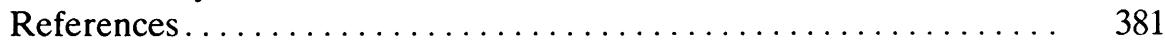

CHAPTER 68

Hormonal Regulation of Phospholipid Metabolism via G-proteins II:

PLA $\mathrm{A}_{2}$ and Inhibitory Regulation of PLC

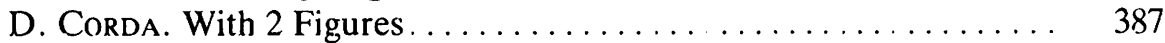

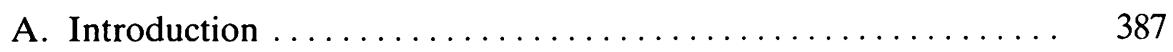

B. Modulation of $\mathrm{PLA}_{2} \ldots \ldots \ldots \ldots \ldots \ldots \ldots \ldots \ldots \ldots \ldots$

I. Molecular Forms of $\mathrm{PLA}_{2} \ldots \ldots \ldots \ldots \ldots \ldots \ldots \ldots$

II. G-Protein-Mediated Activation of $\mathrm{PLA}_{2} \ldots \ldots \ldots \ldots \ldots$

III. Molecular Aspects . . . . . . . . . . . . . . . . . . . . . 390

IV. Inhibitory Regulation of $\mathrm{PLA}_{2} \ldots \ldots \ldots \ldots \ldots \ldots \ldots \ldots$

C. Activity of PLA $\mathrm{PL}_{2}$ in ras-Transformed Cells . . . . . . . . . . . . 392

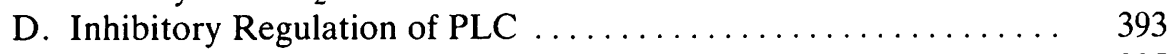

I. Molecular Aspects ... . . . . . . . . . . . . . . . . . . . . 395

E. Conclusion ........................... 396

References.............................. 396

CHAPTER 69

G-Protein Regulation of Phospholipase $\mathrm{C}$ in the Turkey Erythrocyte A.J. Morris, D.H. Maurice, G.L. Waldo, J.L. Boyer, and T.K. HARDEN

A. Introduction $\ldots \ldots \ldots \ldots \ldots \ldots \ldots \ldots \ldots \ldots \ldots \ldots \ldots \ldots \ldots$

B. Properties of $\mathrm{P}_{2 \mathrm{Y}}$ Purinergic Receptor and G-Protein-Regulated

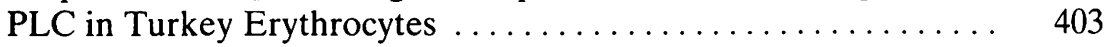

I. Initial Observations . . . . . . . . . . . . . . . . . . . . 403

II. Kinetics of Activation of PLC by $\mathrm{P}_{2 \mathrm{Y}}$ Purinergic Receptor Agonists and Guanine Nucleotides. 
C. Identification, Purification, and Primary Structure of the Protein Components of the Turkey Erythrocyte Inositol Lipid-Dependent Signaling System

I. G-Protein-Regulated PLC .................... 405

1. Purification and Properties of a G-Protein-Regulated PLC from Turkey Erythrocytes

406

2. Receptor and G-Protein Regulation of the Purified Turkey Erythrocyte PLC . . . . . . . . . . . . . . . . . . . 407

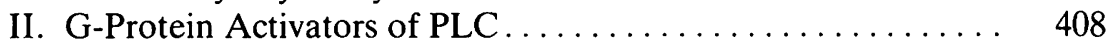

1. Purification and Properties of the Turkey Erythrocyte PLC-Activating G-Protein

2. cDNA Sequence of the Turkey Erythrocyte PLCActivating G-Protein and its Relationship to Mammalian G-Protein $\alpha$ Subunits ........................

D. Concluding Comments ......................... 411

References............................... 412

CHAPTER 70

Hormonal Inhibition of Adenylyl Cyclase by $\alpha_{\mathbf{i}}$ and $\beta \gamma, \alpha_{\mathrm{i}}$ or $\beta \gamma, \alpha_{\mathrm{i}}$ and $/$ or $\beta \gamma$

J.D. Hildebrandt. With 2 Figures .................... 417

A. Introduction .............................. 417

B. Mechanism(s) Mediating Inhibition of Adenylyl Cyclase ...... 418

I. Direct Inhibition of Adenylyl Cyclase by $\alpha_{i} \ldots \ldots \ldots \ldots \ldots .418$

II. Indirect Inhibition of Adenylyl Cyclase by $\beta \gamma$ Suppression of $\alpha_{\mathrm{s}}$ Activation ............................ 419

III. Direct Inhibition of Adenylyl Cyclase by $\beta \gamma \ldots \ldots \ldots \ldots \ldots .420$

C. Current View of Inhibition of Adenylyl Cyclase ........... 421

I. The Mechanism of Inhibition of Adenylyl Cyclase in S49 Cells .................................. 422

II. Significance and Predications of Multiple Mechanism for Inhibition ............................ 424

III. Unresolved Structural and Functional Issues about G-proteins Affecting the Mechanism(s) Mediating Hormone Inhibition of Adenylyl Cyclase . . . . . . . . . 425

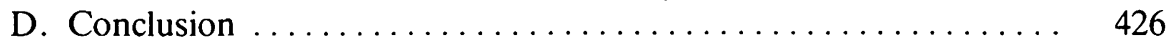

References............................... 426

\section{CHAPTER 71}

Neurobiology of $\mathbf{G}_{\mathrm{o}}$

P. Brabet, V. Homburger, and J. Bockaert. With 3 Figures ..... 429

A. Introduction . . . . . . . . . . . . . . . . . . . . . 429 
B. Gene Structure of $\mathrm{G}_{\mathrm{o}} \alpha$ in Vertebrates and Invertebrates ...... 429

I. Gene Structure and Transcription in Vertebrates........ 429

II. Gene Structure and Transcription in Invertebrates ....... 430

C. Cellular Expression of $G_{o}$ in Excitable Cells and Its Regulation .. 432

I. Cellular and Subcellular Distribution .............. 432

1. Neurons ............................... 432

2. Nonneuronal Cells ..................... 434

II. Control of $\mathrm{G}_{\mathrm{o}}, \mathrm{G}_{\mathrm{o} 1}$, and $\mathrm{G}_{\mathrm{o} 2}$ Expression During Neuronal Differentiation ..................................... 435

D. Neurotransmitter Receptors Coupled to $G_{o}$ and Their Inhibitory Effects on Voltage-Sensitive $\mathrm{Ca}^{2+}$ Channels ............. 436

I. Nature of Receptors ..................... 436

1. Reconstitution of Resolved Receptors and $G_{0}$-Proteins ... 436

2. Reconstitution of Receptor Coupling to VSCC with $\mathrm{G}_{\mathrm{o}^{-}}$ Protein in PTX-Treated Cells .................... 436

3. Stimulation of $G_{o}$ Photolabeling with $\left[\alpha-{ }^{32} P\right] G T P$ Azidoanilide by Neurotransmitters

4. Intracellular Injections of G-protein Antibodies and of Antisense Oligonucleotides Complementary to G-Protein or DNA Sequences To Demonstrate the Specificity of the Negative Coupling Between Receptors and VSCC

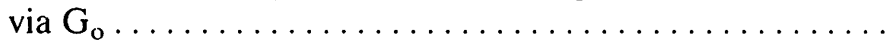

5. Immunoprecipitation of Receptor- $\mathrm{G}_{\mathrm{o}}$ Complexes with Anti- $G_{o}$ Antibodies and Anti-receptor Antibodies .......

II. Nature of VSCC Inhibited by $G_{0} \ldots \ldots \ldots \ldots \ldots \ldots$.

III. Colocalization of $\mathrm{G}_{o}$ and L-Type VSCC in T-Tubule...... 440

IV. Conclusions.............................. 441

E. General Conclusion ......................... 441

References................................. 441

\section{CHAPTER 72}

Involvement of Pertussis-Toxin-Sensitive G-Proteins in the Modulation of $\mathrm{Ca}^{2+}$ Channels by Hormones and Neurotransmitters

W. Rosenthal. With 1 Figure . . . . . . . . . . . . . . . . . 447

A. Introduction .................................. 447

B. Inhibitory Modulation of Voltage-Dependent $\mathrm{Ca}^{2+}$ Channels ... 447

I. Occurrence; Physiological Significance .............. 447

II. Effects of Receptor Agonists, Pertussis Toxin, and Guanine Nucleotides ................................. . 449

III. Types of $\mathrm{Ca}^{2+}$ Channels Affected by Inhibitory Receptor Agonists .................................. 450

IV. Mechanistic Aspects ....................... 452

1. Cyclic Nucleotides ..................... 452 
2. Protein Kinase $C$ and Fatty Acids ............. 453

3. Evidence for a Membrane-Delimited Pathway ....... 454

$V$. Identification of the Involved G-Protein ........... 454

1. Occurrence of $G_{0} \ldots \ldots \ldots \ldots \ldots \ldots \ldots \ldots \ldots 454$

2. Reconstitution Experiments with Native and Recombinant G-Proteins; Transfected Cells ........ 455

3. Antibodies ........................... 456

4. $\mathrm{G}_{\mathrm{o}}$-Activating Receptors $\ldots \ldots \ldots \ldots \ldots \ldots \ldots \ldots \ldots \ldots \ldots$

5. Antisense Oligonucleotides................ 457

C. Stimulatory Modulation of Voltage-Dependent $\mathrm{Ca}^{2+}$ Channe; .. 458

I. Occurrence; Physiological Significance ............ 458

II. Effects of Pertussis Toxin and Guanine Nucleotides ...... 459

III. Types of $\mathrm{Ca}^{2+}$ Currents Affected by Stimulatory Receptr Agonists ............................... 460

IV. Mechanistic Aspects ...................... 460

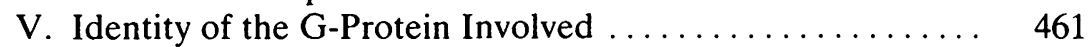

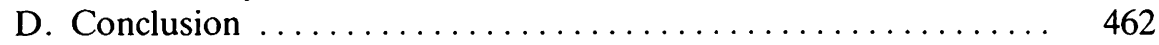

References................................ 463

\section{CHAPTER 73}

Regulation of Cell Growth and Proliferation by $\mathbf{G}_{\mathrm{o}}$

S.D. KROLL and R. IYENGAR. With 3 Figures .............. 471

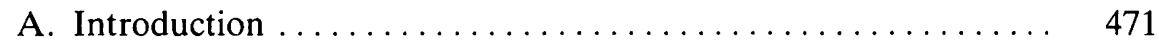

B. The $\mathrm{G}_{0}$-Protein ........................ 471

C. The $\mathrm{G}_{0}$-Protein and Cell Cycle Regulation in the Xenopus Oocyte................................. 473

D. Regulation of Oocyte Maturation by Multiple Pathways....... 477

E. Proliferation of Mammalian Cells by Activated $G_{0} \ldots \ldots \ldots \ldots 478$

F. Specificity of Transformation by Signaling Through G-Protein Pathways............................... 479

G. Desensitization and Growth Signaling Through G-Protein Pathways........................ 481

References................................. 481

\section{CHAPTER 74}

Role of Nucleoside Diphosphate Kinase in G-Protein Action

N. Kimura. With 6 Figures $\ldots \ldots \ldots \ldots \ldots \ldots \ldots \ldots \ldots \ldots \ldots \ldots \ldots$

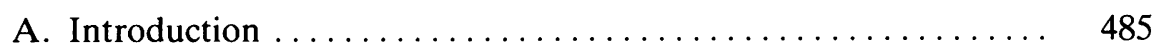

B. General Model of Membrane Signaling Systems Involving
G-Proteins $\ldots \ldots \ldots \ldots \ldots \ldots \ldots \ldots \ldots \ldots \ldots \ldots \ldots \ldots \ldots \ldots \ldots$

C. Role of NDP Kinase in Membrane Signaling Systems ....... 486

I. Evaluation of the Effect of GDP in Comparison with GP .. 486 
II. Role of mNDP Kinase in Signal Transduction .......... 487

III. Comparison Between Hormone and Cholera Toxin Actions 490

IV. Interaction Between mNDP Kinase and $\mathrm{G}_{\mathrm{s}}$, and Its Regulation ............................ 490

V. Regulatory Mechanism of G-Protein by NDP Kinase ...... 491

VI. Physiological Relevance of G-Protein Regulation by mNDP

Kinase ...................................... 494

D. Properties of NDP Kinases and Their Structure ............. 495

E. Novel Roles of NDP Kinases in Cellular Functions . . . . . . . . 495

F. Concluding Remarks .......................... 496

References..................................... 496

\section{CHAPTER 75}

\section{G-Protein Regulation of Cardiac $\mathrm{K}^{+}$Channels}

Y. KURACHI. With 16 Figures . . . . . . . . . . . . . . . . . . . . . . 499

A. Introduction ............................. 499

B. Involvement of G-Protein in Muscarinic Activation of the $\mathrm{K}_{\mathrm{ACh}}$ Channel. . . . . . . . . . . . . . . . . . . . . . . . . . . .... 499

C. Physiological Mode of G-Protein Activation of the $\mathrm{K}_{\mathrm{ACh}}$ Channel ................................... 502

D. Effects of G-Protein Subunits on the Cardiac $\mathrm{K}_{\mathrm{ACh}}$ Channel .... 504

I. Comparison Between the Regulation of Adenylyl Cyclase Activity and the $\mathrm{K}_{\mathrm{ACh}}$ Channel Activity by Purified G-Protein Subunits ............................ 506

II. Effects of $\mathrm{G}_{\beta \gamma}$, on the $\mathrm{K}_{\mathrm{ACh}}$ Channel ............. 507

1. Voltage-Dependent Properties of the $\mathrm{G}_{\beta \gamma}$-Activated $\mathrm{K}_{\mathrm{ACh}}$

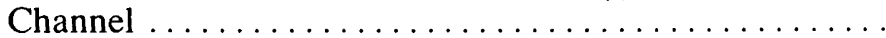

2. Concentration Dependence of $\mathrm{G}_{\beta \gamma}$. Activation of the $\mathrm{K}_{\mathrm{ACh}}$ Channel ................................ 509

3. Specificitiy of $\mathrm{G}_{\beta \gamma}$ Activation of the $\mathrm{K}_{\mathrm{ACh}}$ Channel..... 510

4. $\mathrm{G}_{\beta \gamma}$. Activation of the $\mathrm{K}_{\mathrm{ACh}}$ Channel Is Not Mediated by Phospholipase $\mathrm{A}_{2} \ldots \ldots \ldots \ldots \ldots \ldots \ldots \ldots \ldots \ldots$

5. Antibody 4A Does Not Inhibit the Interaction Between $\mathrm{G}_{\mathrm{K}}$ and the $\mathrm{K}_{\mathrm{ACh}}$ Channel ................. 512

III. Effects of G-Protein on the ATP-Sensitive K Channel ..... 514

E. Stimulatory Modulation of the $\mathrm{G}_{\mathrm{K}}$-Gated Cardiac $\mathrm{K}_{\mathrm{ACh}}$ Channel 515

I. Arachidonic Acid and Its Metabolites ............... 515

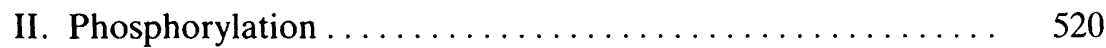

III. NDP-Kinase ............................ 521

IV. Intracellular Chloride $\ldots \ldots \ldots \ldots \ldots \ldots \ldots \ldots \ldots, 522$

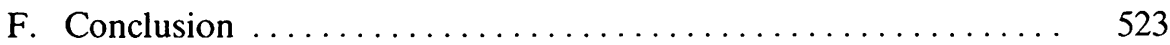

References................................ 523 


\section{CHAPTER 76}

\section{Modulation of $\mathrm{K}^{+}$Channels by G-Proteins}

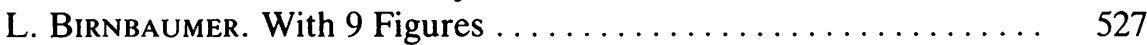

A. Direct Regulation of Ionic Channels by G-Proteins ........ . 527

I. The Inwardly Rectifying "Muscarinic" $\mathrm{K}^{+}$Channel ...... 527

1. Experiments Leading to the Discovery of G-Protein Gating ............................. 527

2. Direct Stimulation by $\mathrm{hRBC} \mathrm{G}_{\mathrm{i}}$ and Its $\alpha$ Subunit $\ldots \ldots \quad 529$

3. Properties of the $\mathrm{G}_{i}$-stimulated $\mathrm{K}^{+}$Channel ........ 532

4. Identity of the $G_{k}$ that Gates the Muscarinic-Type $\mathrm{K}^{+}$ Channels ............................... 534

II. The ATP-Sensitive $\mathrm{K}^{+}$Channel: A Second $\mathrm{G}_{\mathrm{i}}$-Gated $\mathrm{K}^{+}$ Channel ............................. 536

1. General Properties of the ATP-Sensitive $\mathrm{K}^{+}$Channel/ Sulfonyliurea Receptor Complex .

2. Identity of G-proteins that Regulate the ATP-Sensitive

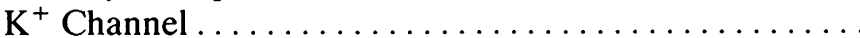

III. G-Protein Gating as a Tool To Discover Novel Ionic

Channels: Neuronal $\mathrm{G}_{\mathrm{o}}$-Gated $\mathrm{K}^{+}$Channels.

B. Effect of $\beta \gamma$ Dimers: Inhibition versus Stimulation of the Muscarinic $\mathrm{K}^{+}$Channel - A Persisting Controversy ..........

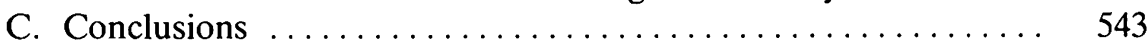

References................................. 544

\section{CHAPTER 77}

ATP-Sensitive $\mathrm{K}^{+}$Channel: Properties, Occurrence, Role in Regulation of Insulin Secretion

U. Panten, C. Schwanstecher, and M. Schwanstecher.

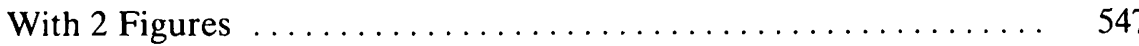

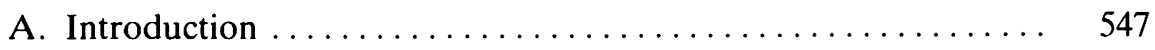

B. Biophysical Properties ......................... 547

C. Regulation of the $\mathrm{K}_{\mathrm{ATP}}$ Channel .................. 548

I. Inhibition by Intracellular Nucleotides . ........... 548

II. Activation by Intracellular Nucleoside Diphosphates .... . 549

III. Activation by Intracellular MgATP . . . . . . . . . . . . 550

IV. Activation by G-Proteins . . . . . . . . . . . . . . . $\quad 550$

V. Inhibition by G-Proteins $\ldots \ldots \ldots \ldots \ldots \ldots \ldots \ldots \ldots \ldots \ldots \ldots \ldots$

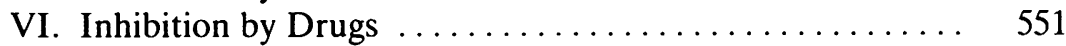

VII. Activation by Drugs ...................... 552

VIII. Characteristics of the Sulfonylurea Receptor ........ 552 
D. Role of the $\mathrm{K}_{\mathrm{ATP}-\mathrm{C}}$ Channel in Regulation of Insulin Secretion ...

CHAPTER 78

Modulation of Maxi-Calcium-Activated K Channels: Role of Ligands, Phosphorylation, and G-Proteins

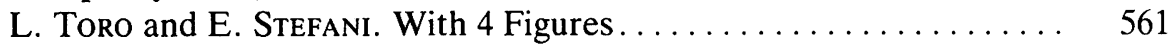

A. Introduction ................................ 561

B. Mechanisms of Metabolic Regulation of Maxi-K $\mathrm{K}_{\mathrm{Ca}}$ Channels . . . 564

I. Ligand Modulation .............................. 564

1. Arachidonic Acid .......................... 564

2. Angiotensin II and Thromboxane $A_{2} \ldots \ldots \ldots \ldots \ldots \quad 565$

3. Guanine Nucleotides ..................... 565

4. Intracellular $\mathrm{pH} \ldots \ldots \ldots \ldots \ldots \ldots \ldots \ldots \ldots \ldots . \ldots \ldots$

II. Phosphorylation/Dephosphorylation Cycles . . . . . . . . 568

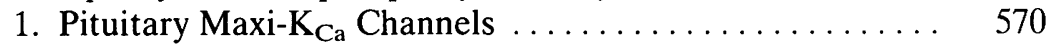

2. Brain Maxi- $\mathrm{K}_{\mathrm{Ca}}$ Channels .................. 570

3. Colonic Maxi- $\mathrm{K}_{\mathrm{Ca}}$ Channels ................. 571

4. Myometrial Maxi- $\mathrm{K}_{\mathrm{Ca}}$ Channels ................ 571

III. G-Protein Gating ........................ 572

1. Muscarinic Regulation ..................... 573

2. Adrenergic Stimulation ...................... 574

C. Conclusions ................................. 575

References................................. 576

\section{CHAPTER 79}

Regulation of the Endosomal Proton Translocating ATPase $\left(\mathrm{H}^{+}\right.$-ATPase) and Endosomal Acidification by G-Proteins

R.W. Gurich and T.D. DuBose, JR. With 6 Figures ........... 581

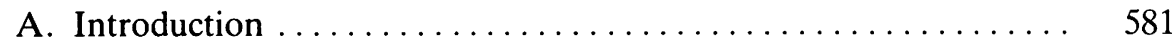

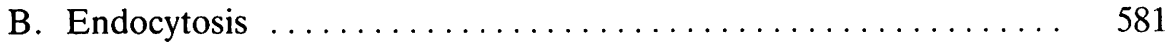

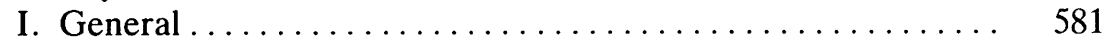

II. The Kidney............................. 582

C. Endosomal Acidification ..................... 584

I. Potential Role for G-Proteins in Endosomal Acidification ... . 586

II. Effects of G-Proteins on Endosomal Acidification......... 588

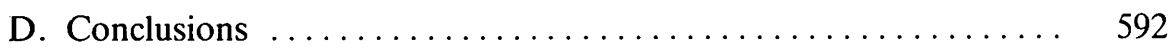

References.................................... 593 
CHAPTER 80

cAMP-Independent Regulation of Adipocyte Glucose Transport Activity and Other Metabolic Processes by a Complex of Receptors and Their Associated G-Proteins

C. Londos and I.A. Simpson. With 4 Figures ............... 597

A. Introduction ............................ 597

B. Lack of a Relationship Between cAMP and Glucose Transporter Activity ................................ 598

C. G-Proteins in Glucose Transporter Regulation............. 600

D. How Do G-Proteins Mediate Glucose Transporter Activity? .... 602

E. Other $R_{s} G_{s}$ and $R_{i} G_{i}$-Mediated Processes in Adipocytes....... 605

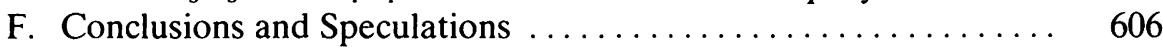

References................................... 607

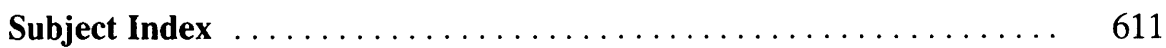




\title{
High-Voltage Activated $\mathrm{Ca}^{2+}$ Channel
}

\author{
F. Hofmann, M. Biel, E. Bosse, R. Hullin, P. Ruth, A. Welling, \\ and V. FLOCKERZI
}

\section{A. Introduction}

Calcium channels are part of the signal system which is vital for intercellular communication in higher multicellular organisms. They transduce electrical or hormonal signals into a chemical second messenger, namely calcium. The cytosolic calcium concentration controls numerous cellular functions by binding to distinct calcium receptor binding proteins such as calmodulin, troponin, or calcium-activated potassium channels. Voltage-dependent calcium channels are of particular interest since their opening or closing determinates the cellular calcium concentration of many cells. In the normal heart they are essential to the generation of normal cardiac rhythm, to impulse propagation through the atrioventricular node, and to contraction in atrial and ventricular muscle. In vascular smooth muscle calcium channels provide part of the calcium that controls smooth muscle contraction and vascular tone. In skeletal muscle they are an essential part of the tubular excitation-contraction coupling mechanism. In neuronal and neuroendocrine cells they are essential for neurotransmitter release (for recent reviews see Bertolino and Llinas 1992; Brown and Birnbaumer 1990; Miller 1992; Rios et al. 1992; Trautwein and Hescheler 1990).

\section{B. Identified cDNAs of High-Voltage Activated Calcium Channels}

High-voltage activated calcium channels are present in many tissues and are the major pathway for voltage-dependent calcium entry in excitable cells. They are activated at a high membrane potential, inactivate slowly (long lasting) and are readily blocked by different compounds. L-type calcium channels are blocked by the organic calcium channel blockers $(\mathrm{CaCB})$ such as nifedipine and verapamil, $\mathrm{N}$-type by $\omega$-conotoxin, and P-type by the funnel web spider toxin $\omega$-Age IVA (MINTZ et al. 1992). The principal channel-forming subunit of a high-voltage activated calcium channel is the $\alpha_{1}$ subunit. When purified from rabbit skeletal muscle, this protein (apparent molecular mass $165 \mathrm{kDa}$ ) is associated with a $55-\mathrm{kDa}$ protein $(\beta)$, a 32-kDa protein $(\gamma)$, and a disulfide-linked dimer of $130 / 28 \mathrm{kDa}\left(\alpha_{2} / \delta\right)$ (see HoRmann et al. 1990 and references cited there). The primary structure of 
Table 1. Classification of cloned and expressed mammalian calcium channel cDNA's

\begin{tabular}{|c|c|c|c|c|c|c|}
\hline Gene & $\begin{array}{l}\text { Snutch } \\
\text { class }\end{array}$ & Source & Species & $\begin{array}{l}\text { Functionally } \\
\text { expressed }\end{array}$ & Sensitive to & Reference \\
\hline \multicolumn{7}{|l|}{$\alpha_{1}$ subunit } \\
\hline \multirow{2}{*}{$\mathrm{CaCh} 2 \mathrm{a}$} & - & Skeletal muscle & Rabbit & Yes & DHP & TANABE et al. 1987 \\
\hline & $\mathrm{C}$ & $\begin{array}{l}\text { Heart } \\
\text { Brain }\end{array}$ & $\begin{array}{l}\text { Rabbit } \\
\text { Rat }\end{array}$ & Yes & DHP & $\begin{array}{l}\text { MiKAMI et al. } 1989 \\
\text { SNUTCH et al. } 1991\end{array}$ \\
\hline \multirow[t]{3}{*}{$\mathrm{CaCh} 2 \mathrm{~b}$} & $\mathrm{C}$ & Lung, smooth muscle & Rabbit & Yes & DHP & BIEL et al. 1990 \\
\hline & & Brain & Rat & - & & SNUTCH et al. 1991 \\
\hline & & Aorta & Rat & Yes & DHP & КосH et al. 1990 \\
\hline \multirow[t]{2}{*}{$\mathrm{CaCh} 3$} & $\mathrm{D}$ & $\begin{array}{l}\text { Brain } \\
\text { Brain }\end{array}$ & $\begin{array}{l}\text { Human } \\
\text { Rat }\end{array}$ & Yes & DHP, $\omega$-conotoxin & WiLLIAMS et al. 1992a \\
\hline & & Pancreatic islet & Human & - & & SEINO et al. 1992 \\
\hline \multirow[t]{2}{*}{$\mathrm{CaCh} 4$} & A & Brain & Rabbit & Yes & Spider venom & Mori et al. 1991 \\
\hline & & Brain & Rat & - & & STARR et al. 1991 \\
\hline \multirow[t]{2}{*}{ CaCh5 } & B & Brain & Human & Yes & $\omega$-Conotoxin & WILLIAMs et al. 1992b \\
\hline & & Brain & Rat & - & $\omega$-Conotoxin & BubEL et al. 1992 \\
\hline \multicolumn{7}{|l|}{$\alpha_{2} / \delta$ subunit } \\
\hline $\mathrm{CaA}_{2} 1 \mathrm{a}$ & - & $\begin{array}{l}\text { Skeletal muscle } \\
\text { Brain }\end{array}$ & $\begin{array}{l}\text { Rabbit } \\
\text { Human }\end{array}$ & $\begin{array}{l}\text { Yes } \\
\text { Yes }\end{array}$ & - & $\begin{array}{l}\text { ELLIS et al. 1988; MiKami et al. } 1989 \\
\text { WILLIAMS et al. 1992a }\end{array}$ \\
\hline $\mathrm{CaA}_{2} \mathrm{lb}$ & - & Brain & Rat & - & & KIM et al. 1992 \\
\hline \\
\hline \multirow{2}{*}{$\mathrm{CaB1}$} & & Brain & Rat & - & & Pragnell et al. 1991 \\
\hline & & Brain & Human & Yes & - & WILLIAMS et al. 1992a \\
\hline \multirow[t]{2}{*}{$\mathrm{CaB} 2^{*}$} & - & Heart & Rabbit & Yes & - & Hullin et al. 1992 \\
\hline & & Brain & Rat & Yes & - & PEREZ-REYES et al. 1992 \\
\hline $\mathrm{CaB3}$ & - & Heart & Rabbit & Yes & - & HULLIN et al. 1992 \\
\hline $\begin{array}{l}\gamma \text { subunit } \\
\mathrm{CaG1}\end{array}$ & - & Skeletal muscle & Rabbit & Yes & - & JAY et al. 1990 ; BosSE et al. 1990 \\
\hline
\end{tabular}

Only full length clones have been included in this table. The nomenclature used for the $\alpha_{1}$ subunit is adapted from PEREZ-REYEs et al. (1990). For the Snutch classes see SNUTCH et al. (1990). The references in the table refer to the first published sequence. In some cases functional expression of the particular clone has been reported in a different publication.

-, not reported; DHP, dihydropyridine; ${ }^{*}$, at least three different variants $(a-c)$ of the same gene have been identified. 


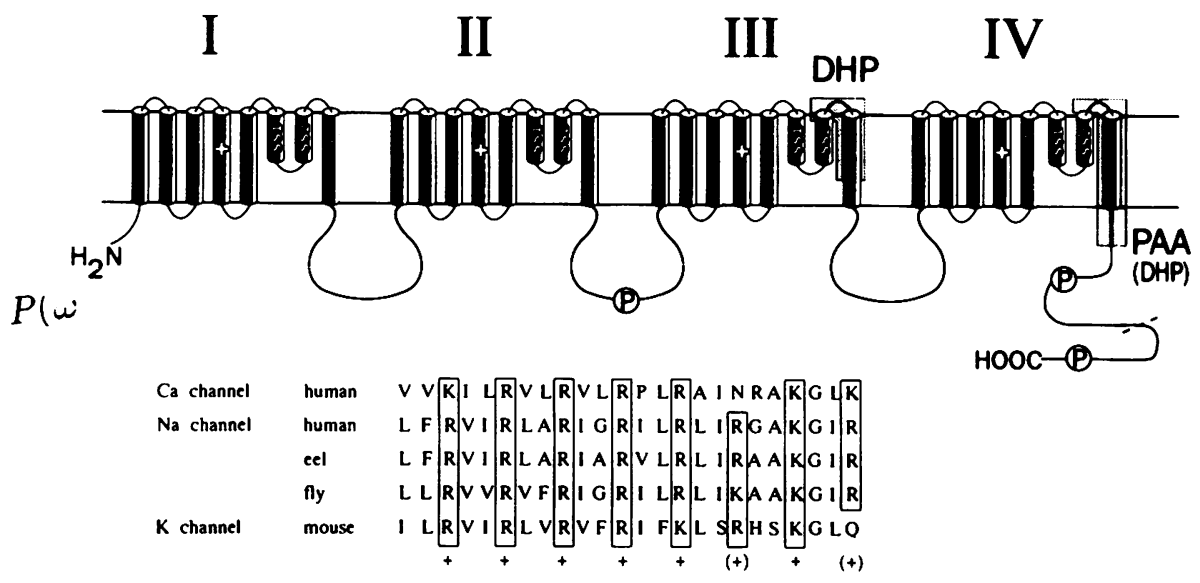

Fig. 1. Proposed topography of the $\alpha_{1}$ subunit of the skeletal muscle calcium channel gene CaCh1. Shaded areas, proposed binding site for dihydropyridines $(D H P)$ and phenylalkylamines $(P A A)$. $P$, the in vitro identified cAMP kinase phosphorylation sites, dashes, the proposed truncation of the carboxy terminus;,+ the amphipathic helix S4. Below, the amphipathic helix S4 sequence is compared with the S4 helices of other voltage-dependent ion channels

these proteins has been deduced by cloning their cDNAs (see Table 1 for references).

\section{The $\alpha_{1}$ Subunit}

Complete cDNA clones of four different $\alpha_{1}$ subunit gene products $(\mathrm{CaCh}$ 1-4) have been sequenced and shown to direct the synthesis of functional calcium channel after expression of their cRNA in Xenopus oocytes or cell culture cells (Table 1). The primary sequences of these different gene products are homologous to each other and predict a transmembrane topology which is similar to that of other voltage-dependent ion channels (Fig. 1). The primary sequences of the $\alpha_{1}$ subunits predict proteins of $212-273 \mathrm{kDa}$ containing four homologous repeats, each of which is composed of five hydrophobic putative transmembrane $\alpha$ helices and one amphipathic segment (S4) (TANABE et al. 1987; Fig. 1). The "extracellular" loop between the transmembrane helices 5 and 6 (SS1-SS2 region) is predicted to fold into the membrane and to form part of the pore of the channel (GUY and CONTI 1990). The skeletal and the cardiac/smooth muscle calcium channels are encoded by two different genes, $\mathrm{CaCh} 1$ and $\mathrm{CaCh} 2$. Several splice variants of the $\mathrm{CaCh} 2$ gene have been identified (BIEL et al. 1991). One major difference is the presence of two different exons at the transmembrane region IV S3 which alternate between the cardiac $(\mathrm{CaCh} 2 \mathrm{a})$ and smooth muscle $(\mathrm{CaCh} 2 \mathrm{~b})$ isochannels. Polymerase chain reaction (PCR) amplification of the sequences around IV S3 suggests that a deletion within 
each exon results in two additional splice variants (Perez-ReYes et al. 1990). The two alternative channels $\mathrm{CaCh} 2 \mathrm{a}$ and $\mathrm{CaCh} 2 \mathrm{~b}$ have been expressed stably in CHO-cells.

No major differences in basic electrophysiological characteristics have been observed, including the amplitude and voltage dependence of inward current and time of activation and inactivation (WelLiNG et al. 1992b). However, the two splice variants are expressed differentially in heart and smooth muscle (BIEl et al. 1991) and during cardiac development (Diebold et al. 1992). The third gene is expressed in neuroendocrine tissues, whereas the forth gene appears to be brain specific. The currents induced by the expression of the $\mathrm{CaCh} 1, \mathrm{CaCh} 2$, and $\mathrm{CaCh} 3$ genes are inhibited by low concentrations of dihydropyridines and therefore are classified as L-type calcium channels. The neuroendocrine channel $\mathrm{CaCh} 3$ is inhibited only at rather high concentration by $\omega$-conotoxin and is not an $\mathrm{N}$-type calcium channel. The current through the $\mathrm{CaCh} 4$ gene product is not affected by dihydropyridines but is inhibited by low concentrations of a mixture of the funnel web spider toxines and has been classified as a neuronal P-type channel. The $\alpha_{1}$ subunit of $\mathrm{CaCh} 5$ has a high-affinity $\omega$-conotoxin binding site (Dubel et al. 1992; Williams et al. 1992b) and is expressed as calcium channel only in the presence of the $\beta$ and $\alpha_{2}$ subunits. The current is inhibited at picomolar concentrations of $\omega$-conotoxin (Williams et al. 1992b), identifying the $\mathrm{CaCh} 5$ protein as a neuronal $\mathrm{N}$-type channel.

\section{The $\alpha_{2} / \delta$ Subunit}

The deduced amino acid sequence of the $\alpha_{2} / \delta$ protein is that of a membrane protein of $125018 \mathrm{Da}$ (Ellis et al. 1988; Table 1). It contains three putative transmembrane segments and a large extracellular domain with several consensus sequences for glycosylation. The $\delta$ subunit sequence is identical with the carboxy terminal part of the deduced primary structure of the $\alpha_{2}$ cDNA starting at amino acid 935 of the predicted sequence (DE JONGH et al. 1990). Presumably, the mature $\alpha_{2}$ and $\delta$ proteins are the product of the same gene and arise by posttranslational processing. The mature $\alpha_{2}$ protein may be located completely extracellularly, linked by a disulfide bridge to the transmembrane $\delta$ protein (JAY et al. 1991). Immuno- (NoRMAN et al. 1987) and northern blots (Ellis et al. 1990; Biel et al. 1991) show that the $\alpha_{2} / \delta$ protein is expressed in skeletal muscle, heart, brain, airway, vascular, and intestinal smooth muscle. Northern blots have identified a predominant 8-kB and a low-abundance 7-kB transkript with a skeletal muscle $\alpha_{2}$ probe at high and low stringency (Biel et al. 1991). Recently an $\alpha_{2} / \delta$ cDNA has been cloned from human brain which is identical to the skeletal muscle $\alpha_{2} / \delta$ cDNA (Williams et al. 1992a). A splice variant of this $\alpha_{2} / \delta$ gene has been cloned from rat brain, which differs in part from the putative $\alpha_{2}$ proteins but contains an identical $\delta$ protein (KIM et al. 1992). These results suggest that heart, brain, and smooth muscle express a conserved $\alpha_{2}$ protein whereas brain contains an additional $\alpha_{2} / \delta$ protein. 


\section{The $\beta$ Subunit}

The deduced primary sequence of the skeletal muscle $\beta$ subunit is compatible with that of a peripheral membrane protein of $57868 \mathrm{Da}$ (Table 1 ; RUTH et al. 1989). It contains four $\alpha$-helical domains, each of which contains a homologous stretch of eight amino acids. Domains II, IIII, and IV contain a heptad repeat structure. Heptad repeats have been found in cytoskeletal proteins. This suggests that the $\beta$ subunit may be a cytoskeletal protein which anchors the $\alpha_{1}$ subunit to the cytoskeleton. The $\beta$-like proteins which are different from the skeletal muscle $\beta$ subunit exist in heart, aorta, and brain and are derived from two different genes $(\mathrm{CaB} 2$ and $\mathrm{CaB} 3$; Hullin et al. 1992). The primary transcript of $\mathrm{CaB} 2$ is differentially spliced and leads to the expression of at least three different isoforms (CaB2a, $\mathrm{CaB} 2 \mathrm{~b}$, and $\mathrm{CaB} 2 \mathrm{c})$. The overall homology between the novel $\beta$ subunits found in heart, aorta, and brain and the skeletal muscle $\beta$ subunit $(\mathrm{CaB} 1)$ is $71 \%$ for $\mathrm{CaB} 2 \mathrm{a}, 71.5 \%$ for $\mathrm{CaB} 2 \mathrm{~b}$, and $66.6 \%$ for $\mathrm{CaB} 3$. Northern blot and $\mathrm{PCR}$ analyses show that $\mathrm{CaB} 1$ is present in large amounts in skeletal muscle and brain, $\mathrm{CaB} 2$ in heart and aorta, and $\mathrm{CaB} 3$ in brain and tissues which are rich in smooth muscle such as aorta, lung, and trachea.

\section{The $\gamma$ Subunit}

The deduced primary sequence of the skeletal muscle $\gamma$ subunit is in agreement with that of an integral membrane protein of $25058 \mathrm{Da}$ (Table 1; Bosse et al. 1990; JAY et al. 1990). The deduced sequence contains four putative transmembrane domains and two glycosylation sites which are located extracellularly. A complete cDNA for the $\gamma$ subunit has been detected only in skeletal muscle. Northern and PCR analyses have not indicated that the same mRNA is present in higher concentrations in other tissues.

\section{Structure-Function of the Cloned Calcium Channel Proteins}

\section{Expression and Function of the Channel Subunits}

The cloned cDNA of the four calcium channel genes has been expressed in different cells (Table 2). The skeletal muscle $\alpha_{1}$ subunit (CaCh1) has been expressed in L cells (Perez-Reyes et al. 1989; LaCERDA et al. 1991; VARADI et al. 1991) and skeletal muscle myotubes from mice with the muscular dysgenesis mutation (TANABE et al. 1988). Neither cell type has a functional $\alpha_{1}$ subunit. The mice myotubes contained the $\alpha_{2}$ and the other subunits may also be present. Expression of the skeletal muscle $\alpha_{1}$ subunit (CaCh1) in L cells induces a barium current which activates extremely slowly $\left(\tau_{\text {act. }}\right.$ $\approx 665 \mathrm{~ms}$; Perez-ReYes et al. 1989). Channel activation is accelerated 75 -fold 
Table 2. Functional effects of calcium channel subunits on currents induced by different $\alpha_{1}$ subunits

\begin{tabular}{|c|c|c|c|c|c|c|c|}
\hline$\alpha_{1}$ Gene & $\begin{array}{l}\text { Subunits } \\
\text { expressed }\end{array}$ & $\begin{array}{l}\text { Cell } \\
\text { line }\end{array}$ & $\begin{array}{l}\text { DHP } \\
\text { sites }_{a}\end{array}$ & $\mathrm{I}_{\mathrm{Ba}}{ }^{\mathrm{b}}$ & $\begin{array}{l}\text { Activation } \\
\text { time }\end{array}$ & $\begin{array}{l}\text { Voltage } \\
\text { dependence }\end{array}$ & Reference \\
\hline \multicolumn{8}{|c|}{ Heterologous subunits } \\
\hline $\mathrm{CaCh} 2 \mathrm{a}$ & $\alpha_{2}$ & Oocyte & - & $(\uparrow)$ & - & - & MiKamI et al. 1989 \\
\hline $\mathrm{CaCh} 2 \mathrm{a}$ & $\alpha_{2}$ & Oocyte & - & $(\uparrow)$ & $\downarrow$ & $(\uparrow)$ & SINGER et al. 1991 \\
\hline $\mathrm{CaCh} 2 \mathrm{a}$ & $\beta$ & Ooctye & - & $(\uparrow$ & $(\downarrow)$ & $(\uparrow)$ & SINGER et al. 1991 \\
\hline $\mathrm{CaCh} 2 \mathrm{a}$ & $\gamma$ & Oocyte & - & $(\uparrow)$ & $(\downarrow)$ & $\uparrow \uparrow$ & SINGER et al. 1991 \\
\hline $\mathrm{CaCh} 2 \mathrm{a}$ & $\alpha_{2} \beta$ & Oocyte & - & $\uparrow \uparrow$ & $\downarrow$ & $\uparrow$ & SINGER et al. 1991 \\
\hline $\mathrm{CaCh} 2 \mathrm{a}$ & $\alpha_{2} \beta \gamma$ & Oocyte & - & $\uparrow$ & $\downarrow$ & $\uparrow \uparrow$ & SINGER et al. 1991 \\
\hline $\mathrm{CaCh} 2 \mathrm{a}$ & $\beta$ & Oocyte & - & & & $\approx$ & WEI et al. 1991 \\
\hline $\mathrm{CaCh} 2 \mathrm{a}$ & $\beta \gamma$ & Oocyte & - & $\uparrow$ & $(\downarrow)$ & $(\uparrow)$ & WEI et al. 1991 \\
\hline $\mathrm{CaCh} 2 \mathrm{~b}$ & $\beta$ & $\mathrm{CHO}$ & $\uparrow$ & & $(\downarrow)$ & $(\uparrow)$ & WeLLING et al. 1992 \\
\hline $\mathrm{CaCh} 2 \mathrm{a}$ & $\beta$ & Oocyte & - & $(\uparrow)$ & - & - & ITAGAKI et al. 1992 \\
\hline $\mathrm{CaCh} 3$ & $\beta$ & Ooctye & - & & - & - & WILLIAMS et al. 1992a \\
\hline $\mathrm{CaCh} 4$ & $\alpha_{2} \beta$ & Ooctye & - & $\uparrow \uparrow$ & - & - & Mori et al. 1991 \\
\hline \multicolumn{8}{|c|}{ Homologous subunits } \\
\hline $\mathrm{CaCh} 1$ & $\beta$ & $\mathrm{L}$ cell & $\uparrow$ & $\approx$ & $\downarrow$ & - & LACERDA et al. 1991 \\
\hline $\mathrm{CaCh} 1$ & $\alpha_{2}$ & L cell & $(\uparrow)$ & $\approx$ & $\approx$ & - & VARADI et al. 1991 \\
\hline $\mathrm{CaCh} 1$ & $\beta$ & $\mathrm{L}$ cell & $\uparrow '$ & $\downarrow^{*}$ & $\approx$ & - & VARADI et al. 1991 \\
\hline $\mathrm{CaCh} 1$ & $\gamma$ & L cell & $\downarrow$ & $\downarrow *$ & $\approx$ & - & VARADI et al. 1991 \\
\hline $\mathrm{CaCh} 1$ & $\beta \gamma$ & L cell & $\downarrow$ & $\downarrow *$ & $(\downarrow)$ & - & VARADI et al. 1991 \\
\hline $\mathrm{CaCh} 1$ & $\alpha_{2} \beta \gamma$ & L cell & $(\uparrow)$ & $(\downarrow)$ & - & - & VARADI et al. 1991 \\
\hline $\mathrm{CaCh} 2 \mathrm{a}$ & $\beta_{2}$ & Oocyte & - & $\uparrow$ & $\downarrow$ & - & Hullin et al. 1992 \\
\hline $\mathrm{CaCh} 2 \mathrm{a}$ & $\beta_{3}$ & Oocyte & - & $\uparrow$ & $\downarrow$ & - & HuLbin et al. 1992 \\
\hline $\mathrm{CaCh} 2 \mathrm{a}$ & $\beta_{2}$ & Oocyte & - & $\uparrow$ & $\downarrow$ & $(\uparrow)$ & Perez-Reyes et al. 1992 \\
\hline $\mathrm{CaCh} 2 \mathrm{a}$ & $\beta_{2}$ & COS & $\uparrow$ & - & - & - & PEREZ-REYEs et al. 1992 \\
\hline $\mathrm{CaCh} 5$ & $\alpha_{2} \beta$ & HEK293 & $\uparrow \uparrow \S$ & $\uparrow \uparrow$ & - & - & WILLIAMS et al. $1992 \mathrm{~b}$ \\
\hline
\end{tabular}

All effects are compared with that of cells expressing only the $\alpha_{1}$ subunit.

${ }^{a}$ The number of dihydropyridine binding sites per mg protein.

${ }^{\mathrm{b}}$ Barium inward current.

${ }^{\mathrm{c}} \mathrm{A}$ shift in voltage dependence of the I/V curve or steady state activation or inactivation to more negative values.

$\alpha_{2}, \beta$ and $\gamma$ are identical with $\mathrm{CaA} 1 \mathrm{a}, \mathrm{CaB} 1$ and $\mathrm{CaG} 1$. - , not reported; $\approx$, similar to cells expressing $\alpha_{1}$ alone; ${ }^{*}, \mathrm{I}_{\mathrm{Ba}}$ not sensitive to BayK 8644. $(\uparrow), \uparrow$, and $\uparrow \uparrow$ small, moderate and large increase or shift; $(\downarrow)$ and $\downarrow$, small and moderate decrease; $\S, \omega$-conotoxin binding sites. 
( $\tau_{\text {act. }} \approx 8 \mathrm{~ms}$ ) by the coexpression of the skeletal muscle $\beta$ subunit $(\mathrm{CaB} 1$; LACERDA et al. 1991). Expression of the skeletal muscle $\alpha_{1}$ subunit in the dysgenic myotubes generates cells with a slowly activating calcium current and normal skeletal muscle excitation-contraction coupling, which does not depend on the influx of calcium (TANABE et al. 1988). Expression of the cardiac muscle $\alpha_{1}$ subunit ( $\mathrm{CaCh} 2 \mathrm{a}$ ) produces myotubes with $\mathrm{Ca}^{2+}$ currents and excitation contraction coupling as in cardiac muscle (TANABE et al. 1990). TANABE et al. (1990) constructed several chimeras by starting with the cardiac muscle $\alpha_{1}$ subunit and introducing skeletal musclelike intracellular loops. Changing the large intracellular loop that connects repeats II and III switched the mode of excitation-contraction coupling to that characteristic of skeletal muscle. Interestingly, however, the $\mathrm{Ca}^{2+}$ current produced by this chimera remained characteristic of cardiac muscle, i.e., rapidly activating. Chimeras in which the four homologous repeats of the cardiac muscle protein were each switched to the equivalent skeletal muscle sequence showed that changing merely the first homologous repeat switched the characteristics of the $\mathrm{Ca}^{2+}$ current from fast activating (cardiac type) to slowly activating (skeletal muscle type) whereas switching the other three repeats did not have this effect (TANABE et al. 1991).

Stable expression of the $\alpha_{1}$ subunits from smooth muscle $(\mathrm{CaCh} 2 \mathrm{~b})$ in $\mathrm{CHO}$ cells induces dihydropyridine-sensitive barium currents, which have the physiological characteristics as a smooth muscle calcium channel (BossE et al. 1992). The single-channel conductance is $26 \mathrm{pSi}$ in the presence of $80 \mathrm{~m} M \mathrm{Ba}^{2+}$. The channel has the same voltage dependence of activation and inactivation as reported for the naturally occurring smooth muscle calcium channel. The cardiac $\alpha_{1}$ subunit ( $\mathrm{CaCh} 2 \mathrm{a}$ ) cDNA directs the expression of a channel with electrophysiological properties which are indistinguishable from those of the smooth muscle $\alpha_{1}$ subunit (WELLING et al. 1992b). Stable coexpression of the $\mathrm{CaCh} 2 \mathrm{~b}$ protein with the skeletal muscle $\beta$ gene ( $\mathrm{CaB} 1$ ) increases in parallel the number of dihydropyridine binding sites and the amplitude of whole cell barium current, suggesting that the amplitude of inward current is directly related to the number of expressed $\alpha_{1}$ subunits of the protein (WELLING et al. 1993). In addition, the coexpression of the $\beta$ subunit decreases the activation time of the channel by a factor of two and shifts the voltage dependence of steady state inactivation by $18 \mathrm{mV}$ to $-13 \mathrm{mV}$ (Welling et al. 1993). Coexpression of the $\beta$ subunit does not influence the sensitivity of the expressed channel toward the dihydropyridine agonist Bay K 8644. Similar results were obtained by coexpression of the cardiac ( $\mathrm{CaCh} 2 \mathrm{a})$, smooth muscle ( $\mathrm{CaCh} 2 \mathrm{~b})$, neuroendocrine $(\mathrm{CaCh} 3)$, and neuronal $(\mathrm{CaCh} 4) \alpha_{1}$ subunit with the skeletal muscle $\beta$ subunit ( $\mathrm{CaB} 1$ ) in Xenopus oocytes (Table 2 ). In each case the current density increased with coexpression of the $\beta$ subunit (CaB1). Expression of the $\mathrm{N}$ type $\alpha_{1}$ subunit $\mathrm{CaCh} 5$ in $\mathrm{HEK} 239$ cells requires the presence of a neuronal $\beta(\mathrm{CaB} 1)$ and $\alpha_{2}$ subunit to induce $\omega$-conotoxin binding sites and calcium current (Williams et al. 1992b). 
The coexpression of the $\alpha_{1}(\mathrm{CaCH} 2 \mathrm{a})$ and $\beta(\mathrm{CaB} 1-3)$ subunit together with the $\alpha_{2}$ subunit cRNA enhanced also the barium current in Xenopus oocytes. In Xenopus oocytes the $\alpha_{2}$ subunit (Singer et al. 1991) and the $\beta$ subunit (WEI et al. 1991) decreased the activation time of the channel (CaCh2a). Identical results were observed when the cardiac $\alpha_{1}$ subunit (CaCh2a) was coexpressed with the cardiac $(\mathrm{CaB} 2)$ or the smooth muscle/ neuronal (CaB3) $\beta$ subunit and the $\alpha_{2}$ subunit (Huluin et al. 1992) in Xenopus oocytes. The skeletal muscle $\gamma$ subunit $(\mathrm{CaG} 1)$ shifted the voltage dependence of steady-state inactivation of the cardiac $\alpha_{1}$ subunit $(\mathrm{CaCh} 2 \mathrm{a})$ by $40 \mathrm{mV}$ to a negative membrane potential as is observed in skeletal muscle. These results suggest that (a) the skeletal muscle $\beta$ subunit interacts with different $\alpha_{1}$ subunits, (b) the $\beta$ subunits increase barium currents by increasing the number of functional calcium channel proteins, and (c) the $\beta$ subunits affect the activation time of the channel and the voltage dependence of steady-state inactivation. These conclusions are not supported by the experiments of VARADI et al. (1991), who reported that homologous coexpression of skeletal muscle $\alpha_{1}$ and $\beta, \alpha_{1}$ and $\gamma, \alpha_{1}, \beta$ and $\gamma$, $\alpha_{1}, \alpha_{2}, \beta$ and $\gamma$ in L cells decreases the inward current and the stimulatory effect of the calcium channel agonist Bay K 8644. The latter results are difficult to reconcile with those from other laboratories. They could be caused by a nonstoichiometric expression of the channel subunits, i.e., a higher expression of the $\beta$ subunit than the $\alpha_{1}$ subunit (LoRy et al. 1992).

\section{The Binding Sites for Calcium Channel Blockers}

Photoaffinity labeling of the skeletal muscle $\alpha_{1}$ subunit and expression of $\mathrm{CaCh} 1$ and $\mathrm{CaCH} 2 \mathrm{~b}$ gene in $\mathrm{L}$ cells (KIM et al. 1990) or CHO cells (Bosse et al. 1992) shows that the $\alpha_{1}$ subunit itself contains the binding sites for the known organic calcium channel blockers, the dihydropyridines, phenylalkylamines, and benzothiazepines. Binding of these drugs requires the binding of calcium to a high-affinity binding site (SCHNEIDER et al. 1991; STAUDINGER et al. 1991). The allosteric modulation of the dihydropyridine binding site by phenylalkylamine and benzothiazepine is preserved within each $\alpha_{1}$ subunit (KIM et al. 1990; Bosse et al. 1992). The current induced in cell culture cells or Xenopus oocytes by the $\mathrm{CaCh} 1, \mathrm{CaCh} 2 \mathrm{a}$, and $\mathrm{CaCh} 2 \mathrm{~b}$ proteins is increased by Bay $\mathrm{K} 8644$, a calcium channel agonist, and is inhibited by the known calcium channel blockers.

Photoaffinity labeling of the purified skeletal muscle $\alpha_{1}$ subunit by dihydrophyridines and phenylalkylamines suggests that the dihydropyridines bind to the SS1-SS2 region of repeat III (STRIESSNIG et al. 1991; NAKAYAMA et al. 1991) and apparently to a sequence following IVS6 (REgulLA et al. 1991) (Fig. 1). The extracellular location of the binding site at the SS1-SS2 region of repeat III is supported by the finding that dihydropyridines block the calcium channel from the extracellular space (Kass et al. 1991). The 
phenylalkylamines label a second putative intracellular site located directly after the IVS6 (STRIESSNIG et al. 1990).

\section{Phosphorylation of the Channel Proteins}

The L-type current of cardiac, smooth and skeletal muscle, neuroendocrine, and neuronal calcium channels is modulated by hormones through the $\alpha$ subunits of different G-proteins (Brown and Birnbaumer 1990). The open probability of the cardiac and skeletal muscle and of some neuroendocrine cells is increased by cAMP-dependent phosphorylation, suggesting that phosphorylation of the $\alpha_{1}$ subunit or a different subunit of the calcium channel is important for its hormonal control. In skeletal muscle, about $90 \%$ of the full-length $\alpha_{1}$ subunit ( $\mathrm{CaCh} 1$ ) is apparently processed to a smaller protein with the carboxy terminus being close to amino acid residue 1690 (DE JONGH et al. 1991). cAMP-kinase phosphorylates in vitro rapidly Ser687 (RÖHRKASTEN et al. 1988), which is located at the cytosolic loop between repeat II and III, and Ser-1854 (RoTmAN et al. 1992), which is present only in the full-length skeletal muscle $\alpha_{1}$ subunit, and slowly Ser-1617 (RöHrKasten et al. 1988). Phosphorylation of these sites may be significant, since the open probability of the reconstituted skeletal muscle CaCBreceptor/calcium channel is increased several-fold by cAMP-dependent phosphorylation (FLOCKERZI et al. 1986; HyMEL et al. 1988; NuNOKI et al. 1989; Mundina-Weilenmann et al. 1991). The $\alpha_{1}$ subunit is phosphorylated also in vivo at least at two sites in response to isoproterenol in isolated rat myocytes (LAI et al. 1990; Mundina-WeILENMANN et al. 1991).

These in vivo phosphorylation sites may be identical with Ser-687 and Ser-1854. However, it is not clear which of these phosphorylation sites - one of which is present only in the unprocessed $\alpha_{1}$ subunit - affect the open probability of the skeletal muscle calcium channel. The in vitro identified phosphorylation sites of the $\mathrm{CaCh} 1$ gene are not conserved in the sequences of the other calcium channel genes and therefore are not important for the hormonal regulation of the calcium channel in heart and neuroendocrine cells. The hormonal control of the calcium channels may be exerted by tissue specific $\beta$ subunits. The deduced amino acid sequence of the skeletal $\beta$ subunit ( $\mathrm{CaB} 1)$ contains several potential phosphorylation sites. Two of these sites, Ser-182 and Thr-205, are phosphorylated in vitro by cAMP kinase (RuTH et al. 1988; DE JoNGH et al. 1989). The products of the CaB2 gene contain a cAMP-kinase phosphorylation site equivalent to Thr-205 of $\mathrm{CaB} 1$. This phosphorylation site is not present in the product of $\mathrm{CaB} 3$, which is expressed mainly in brain and smooth muscle (Hullin et al. 1992). This is interesting since in vivo whole cell calcium current is increased in heart (KAMEYAMA et al. 1986) and skeletal muscle (GARCIA et al. 1990) but not smooth muscle (WELling et al. 1992a) by cAMP-dependent phosphorylation. Expression of the cardiac $\alpha_{1}$ subunit with the $\alpha_{2}$ and $\beta$ subunit in Xenopus oocytes indicates that cAMP-dependent regulation of 
the cardiac calcium channel is mediated by phosphorylation of the $\beta$ subunit (KLÖCKNER et al. 1992; DASCAL et al. unpublished observation).

\section{Conclusion}

High-voltage activated calcium channels are encoded by different genes. Their electrophysiological and hormonal regulation may depend on the coexpression of different subunits. The interaction of these channel subunits with additional proteins such as the $\alpha$ subunit of trimeric G-proteins may be required for basic and hormonal regulation of the channel (HAMILTON et al. 1991; Cavalie et al. 1991; Kleuss et al. 1991). The availability of the cloned cDNA of several channel proteins and channel regulators will facilitate understanding of the complexities of voltage-gated calcium channels.

Acknowledgments. The experimental work of the authors was supported by grants from DFG, Fond der chemischen Industrie, und Thyssen Stiftung. We thank Mrs B. Schatz for typing part of the manuscript.

\section{References}

Bertolino M, Llinás R (1992) The central role of voltage-activated and receptor operated calcium channels in neuronal cells. Annu Rev Pharmacol Toxicol 32:399-421

Biel M, Hullin R, Freundner S, Singer D, Dascal N, Flockerzi V, Hofmann F (1991) Tissue-specific expression of high-voltage-activated dihydropyridine-sensitive Ltype calcium channels. Eur J Biochem 200:81-88

Biel M, Ruth P, Bosse E, Hullin R, Stühmer W, Flockerzi V, Hofmann F (1990) Primary structure and functional expression of a high voltage activated calcium channel from rabbit lung. FEBS Lett 269:409-412

Bosse E, Bottlender R, Kleppisch T, Hescheler J, Welling A, Hofmann F, Flockerzi $V$ (1992) Stable and functional expression of the calcium channel $\alpha_{1}$ subunit from smooth muscle in somatic cell lines. EMBO J 11 2033-2038

Bosse E, Regulla S, Biel M, Ruth P, Meyer HE, Flockerzi V, Hofmann F (1990) The cDNA and deduced amino acid sequence of the $\gamma$ subunit of the L-type calcium channel from rabbit skeletal muscle. FEBS Lett 267:153-156

Brown AM, Birnbaumer L (1990) Ionic channels and their regulation by $G$ protein subunits. Annu Rev Physiol 52:197-213

Cavalié A, Allen TJA, Trautwein W (1991) Role of the GTP-binding protein Gs in the $\beta$-adrenergic modulation of cardiac Ca channels. Pflügers Arch 419:433-443

De Jongh KS, Merrick DK, Catterall WA (1989) Subunits of purified calcium channels: a $212-\mathrm{kDa}$ form of $\alpha_{1}$ and partial amino acid sequence of a phosphorylation site of an independent $\beta$ subunit. Proc Natl Acad Sci USA 86:8585-8589

De Jongh KS, Warner C, Catterall WA (1990) Subunits of purified calcium channels; $\alpha_{2}$ and $\delta$ are encoded by the same gene. J Biol Chem 265:14738-14741

De Jongh KS, Warner C, Colvin AA, Catterall WA (1991) Characterization of the two size forms of the $\alpha_{1}$ subunit of skeletal muscle L-type calcium channels. Proc Natl Acad Sci USA 88:10778-10782

Diebold RJ, Koch WJ, Ellinor PT, Wang J-J, Muthuchamy M, Wieczorek DF, Schwartz A (1992) Mutually exclusive exon splicing of the cardiac calcium channel $\alpha_{1}$ subunit gene generates developmentally regulated isoforms in the rat heart. Proc Natl Acad Sci USA 89:1497-1501 
Dubel SJ, Starr TVB, Hell J, Ahlijanian MA, Enyeart JJ, Catterall WA, Snutch TP (1992) Molecular cloning of the $\alpha$-1 subunit of an $\omega$-conotoxin-sensitive calcium channel. Proc Natl Acad Sci USA 89:5058-5062

Ellis SB, Williams ME, Ways NR, Brenner R, Sharp AH, Leung AT, Campbell KP, McKenna E, Koch WJ, Hui A, Schwartz A, Harpold MM (1988) Sequence and expression of mRNAs encoding the $\alpha_{1}$ and $\alpha_{2}$ subunits of a DHP-sensitive calcium channel. Science 241:1661-1664

Flockerzi V, Oeken HJ, Hofmann F, Pelzer D, Cavalié A, Trautwein W (1986) Purified dihydropyridine-binding site from skeletal muscle t-tubules is a functional calcium channel. Nature 323:66-68

Garcia J, Gamboa-Aldeco R, Stefani E (1990) Charge movement and calcium currents in skeletal muscle fibers are enhanced by GTP $\gamma$ S. Pflügers Arch 417:114-116

Guy HR, Conti F (1990) Pursuing the structure and function of voltage-gated channels. TiNS 13:201-206

Hamilton S, Codina J, Hawkes MJ, Yatani A, Sawada T, Strickland FM, Froehner SC, Spiegel AM, Toro L, Stefani E, Birnbaumer L, Brown AM (1991) Evidence for direct interaction of $\mathrm{G}_{\mathrm{s}} \alpha$ with the $\mathrm{Ca}^{2+}$ channel of skeletal muscle. $J$ Biol Chem 266:19528-19535

Hofmann F, Flockerzi V, Nastainczyk W, Ruth P, Schneider T (1990) The molecular structure and regulation of muscular calcium channels. Curr Top Cell Regulation 31:223-239

Hui A, Ellinor PT, Krizanova O, Wang J-J, Diebold RJ, Schwartz A (1991) Molecular cloning of multiple subtypes of a novel rat brain isoform of the $\alpha_{1}$ subunit of the voltage-dependent calcium channel. Neuron 7:35-44

Hullin R, Singer-Lahat D, Freichel M, Biel M, Dascal N, Hofmann F, Flockerzi V (1992) Calcium channel $\beta$ subunit heterogeneity: functional expression of cloned cDNA from heart, aorta and brain. EMBO J 11:885-890

Hymel L, Striessnig J, Glossmann H, Schindler H (1988) Purified skeletal muscle 1,4-dihydropyridine receptor forms phosphorylation-dependent oligomeric calcium channels in planar bilayers. Proc Natl Acad Sci USA 85:4290-4294

Itagaki K, Koch WJ, Bodi I, Klöckner U, Slish DF, Schwartz A (1992) Native-type DHP-sensitive calcium channel currents are produced by cloned rat aortic smooth muscle and cardiac $\alpha_{1}$ subunits expressed in Xenopus laevis oocytes and are regulated by $\alpha_{2}$ and $\beta$-subunits. FEBS Lett 297:221-225

Jay SD, Ellis SB, McCue AF, Williams ME, Vedvick TS, Harpold MM, Campbell K (1990) Primary structure of the $\gamma$ subunit of the DHP-sensitive calcium channel from skeletal muscle. Science 248:490-492

Jay SD, Sharp AH, Kahl StD, Vedvick TS, Harpold MM, Campbell KP (1991) Structural characterization of the dihydropyridine-sensitive calcium channel $\alpha_{2}$ subunit and the associated $\delta$ peptides. J Biol Chem 266:3287-3293

Kameyama M, Hescheler J, Hofmann F, Trautwein W (1986) Modulation of Ca current during the phosphorylation cycle in the guinea pig heart. Pflügers Arch 407:123-128

Kass RS, Arena JP, Chin S (1991) Block of L-type calcium channels by charged dihydropyridines. J Gen Physiol 98:63-75

Kim HL, Kim H, Lee P, King RG, Chin HR (1992) Rat brain expresses an alternatively spliced form of the dihydropyridine-sensitive L-type calcium channel alpha-2 subunit. Proc Natl Acad Sci USA 89:3251-3255

Kim HS, Wei X, Ruth P, Perez-Reyes E, Flockerzi V, Hofmann F, Birnbaumer L (1990) Studies on the structural requirements for the activity of the skeletal muscle dihydropyridine receptor/slow $\mathrm{Ca}^{2+}$ channel. J Biol Chem 265:1185811863

Kleuss C, Hescheler J, Ewel C, Rosenthal W, Schultz G, Wittig B (1991) Assignment of G-protein subtypes to specific receptors inducing inhibition of calcium currents. Nature 353:43-49 
Klöckner U, Itagaki K, Bodi I, Schwartz A (1992) $\beta$-Subunit expression is required for cAMP-dependent increase of cloned cardiac and vascular calcium channel currents. Pflügers Arch 420:413-415

Koch WJ, Ellinor PT, Schwartz A (1990) cDNA cloning of a dihydropyridinesensitive calcium channel from rat aorta. J Biol Chem 265:17786-17791

Lacerda AE, Kim HS, Ruth P, Perez-Reyes E, Flockerzi V, Hofmann F, Birnbaumer L, Brown AM (1991) Normalization of current kinetics by interaction between the $\alpha_{1}$ and $\beta$ subunits of the skeletal muscle dihydropyridine-sensitive $\mathrm{Ca}^{2+}$ channel. Nature 352:527-530

Lai Y, Seagar MJ, Takahashi M, Catterall W (1990) Cyclic AMP-dependent phosphorylation of two size forms of $\alpha_{1}$ subunits of L-type calium channels in rat skeletal muscle cells. J Biol Chem 34:20839-20848

Lory P, Varadi G, Schultz D, Schwartz A (1992) Subunit composition regulates the skeletal L-type Ca Channel. FASEB J 6:A406

Mikami A, Imoto K, Tanabe T, Niidome T, Mori Y, Takeshima H, Narumiya S, Numa S (1989) Primary structure and functional expression of the cardiac dihydropyridine-sensitive calcium channel. Nature 340:230-233

Miller RJ (1992) Voltage-sensitive Ca ${ }^{2+}$ channels. J Biol Chem 267:1403-1406

Mintz IM, Venema VJ, Swiderek KM, Lee TD, Bean BP, Adams ME (1992) P-type calcium channels blocked by the spider toxin $\omega$-Aga-IVA. Nature 355:827-830

Mori Y, Friedrich T, Kim M-S, Mikami A, Nakai J, Ruth P, Bosse E, Hofmann F, Flockerzi V, Furuichi T, Mikoshiba K, Imoto K, Tanabe T, Numa S (1991) Primary structure and functional expression from complementary DNA of a brain calcium channel. Nature 350:398-402

Mundina-Weilenmann C, Chang CF, Gutierrez LM, Hosey MM (1991) Demonstration of the phosphorylation of dihydropyridine-sensitive calcium channels in chick skeletal muscle and the resultant activation of the channels after reconstitution. J Biol Chem 266:4067-4073

Nakayama H, Taki M, Striessnig J, Glossmann H, Catterall WA, Kanaoka Y (1991) Identification of 1,4-dihydropyridine binding regions within the $\alpha_{1}$ subunit of skeletal muscle $\mathrm{Ca}^{2+}$ channels by photoaffinity labeling with diazipine. Proc Natl Acad Sci USA 88:9203-9207

Norman RI, Burgess AJ, Allen E, Harrison TM (1987) Monoclonal antibodies against the 1,4-dihydropyridine receptor associated with voltage-sensitive $\mathrm{Ca}^{2+}$ channels detect similar polypeptides from a variety of tissues and species. FEBS Letters 212:127-132

Nunoki K, Florio V, Catterall WA (1989) Activation of purified calcium channels by stoichiometric protein phosphorylation. Proc Natl Acad Sci 86:6816-6820

Perez-Reyes E, Castellano A, Kim HS, Bertrand P, Baggstrom E, Lacerda A, Wei $X$, Birnbaumer L (1992) Cloning and expression of cardiac/brain $\beta$ subunit of the L-type calcium channel. J Biol Chem 267:1792-1797

Perez-Reyes E, Kim HS, Lacerda AE, Horne W, Wei X, Rampe D, Campbell KP, Brown AM, Birnbaumer L (1989) Induction of calcium currents by the expression of the $\alpha_{1}$ subunit of the dihydropyridine receptor from skeletal muscle. Nature 340:233-236

Perez-Reyes E, Wei X, Castellano A, Birnbaumer L (1990) Molecular diversity of L-type calcium channel. Evidence for alternative splicing of the transcripts of three non-allelic genes. J Biol Chem 265:20430-20436

Pragnell M, Sakamoto J, Jay SD, Campbell KP (1991) Cloning and tissue-specific expression of the brain calcium channel $\beta$-subunit. FEBS Lett 291:253-258

Regulla S, Schneider T, Nastainczyk W, Meyer HE, Hofmann F (1991) Identification of the site of interaction of the dihydropyridine channel blockers nitrendipine and azidopine with the calcium-channel $\alpha_{1}$ subunit. EMBO J $10: 45-49$

Rios E, Pizarro G, Stefani E (1992) Charge movement and the nature of signal transduction in skeletal muscle excitation-contraction coupling. Annu Rev Physiol 54:251-275 
Röhrkasten A, Meyer HE, Nastainczyk W, Sieber M, Hofmann F (1988) cAMPdependent protein kinase rapidly phosphorylates serine-687 of the skeletal muscle receptor for calcium channel blockers. J Biol Chem 263:15325-15329

Rotman EI, Florio V, Lai Y, De Jongh D, Catterall WA (1992) Specific phosphorylation of a C-terminal site on the $212 \mathrm{kDa}$ form of the $\alpha_{1}$ subunit of the skeletal muscle calcium channel by cAMP-dependent protein kinase. FASEB J 6:A246

Ruth P, Röhrkasten A, Biel M, Bosse E, Regulla S, Meyer HE, Flockerzi V, Hofmann F (1989) Primary structure of the $\beta$ subunit of the DHP-sensitive calcium channel from skeletal muscle. Science $245: 1115-1118$

Schneider T, Regulla S, Hofmann F (1991) The devapamil-binding site of the purified skeletal muscle receptor for organic-calcium channel blockers is modulated by micromolar and millimolar concentrations of $\mathrm{Ca}^{2+}$. Eur $\mathrm{J}$ Biochem 200:245-253

Seino S, Chen L, Seino M, Blondel O, Takeda J, Johnson JH, Bell GI (1992) Cloning of the $\alpha_{1}$ subunit of a voltage-dependent calcium channel expressed in pancreatic $\beta$ cells. Proc Natl Acad Sci USA 89:584-588

Singer D, Biel M, Lotan I, Flockerzi V, Hofmann F, Dascal N (1991) The roles of the subunits in the function of the calcium channel. Science 253:1553-1557

Snutch TP, Leonard JP, Gilbert MM, Lester HA, Davidson N (1990) Rat brain expresses a heterogeneous family of calcium channels. Proc Natl Acad Sci USA 87:3391-3395

Snutch TP, Tomlinson WJ, Leonard JP, Gilbert MM (1991) Distinct calcium channels are generated by alternative splicing and are differentially expressed in the mammalian CNS. Neuron 7:45-57

Starr TVB, Prystay W, Snutch TP (1991) Primary structure of a calcium channel that is highly expressed in the rat cerebellum. Proc Natl Acad Sci USA 88:5621-5625

Staudinger R, Knaus H-G, Glossmann H (1991) Positive heterotopic allosteric regulators of dihydropyridine binding increase the $\mathrm{Ca}^{2+}$ affinity of the L-type $\mathrm{Ca}^{2+}$ channel. J Biol Chem 266:10787-10795

Striessnig J, Glossmann H, Catterall WA (1990) Identification of a phenylalkylamine binding region within the $\alpha_{1}$ subunit of skeletal muscle $\mathrm{Ca}^{2+}$ channels. Proc Natl Acad Sci USA 87:9108-9112

Striessnig J, Murphy BJ, Catterall WA (1991) Dihydropyridine receptor of L-type $\mathrm{Ca}^{2+}$ channels: identification of binding domains for $\left[{ }^{3} \mathrm{H}\right](+)-\mathrm{PN} 200-110$ and $\left[{ }^{3} \mathrm{H}\right]$ azidopine within the $\alpha_{1}$ subunit. Proc Natl Acad Sci USA 88:10769-10773

Tanabe T, Beam KG, Adams BA, Niidome T, Numa S (1990) Regions of the skeletal muscle dihydropyridine receptor critical for excitation-contraction coupling. Nature 346:567-569

Tanabe T, Beam KG, Powell JA, Numa S (1988) Restoration of excitationcontraction coupling and slow calcium current in dysgenic muscle by dihydropyridine receptor complementary DNA. Nature 336:134-139

Tanabe T, Brett AA, Numa S, Beam KG (1991) Repeat I of the dihydropyridine receptor is critical in determining calcium channel activation kinetics. Nature 352:800-803

Tanabe T, Takeshima H, Mikami A, Flockerzi V, Takahashi H, Kangawa K, Kojima M, Matsuo H, Hirose T, Numa S (1987) Primary structure of the receptor for calcium channel blockers from skeletal muscle. Nature 328:313318

Trautwein W, Hescheler J (1990) Regulation of cardiac L-type calcium current by phosphorylation and G-proteins. Annu Rev Physiol 52:257-274

Varadi G, Lory P, Schultz D, Varadi M, Schwartz A (1991) Acceleration of activation and inactivation by the $\beta$ subunit of the skeletal muscle calcium channel. Nature 352:159-162

Wei X, Perez-Reyes E, Lacerda AE, Schuster G, Brown AM, Birnbaumer L (1991) Heterologous regulation of the cardiac $\mathrm{Ca}^{2+}$ channel $\alpha_{1}$ subunit by skeletal muscle $\beta$ and $\gamma$ subunits. J Biol Chem 266:21943-21947 
Welling A, Felbel J, Peper K, Hofmann F (1992a) Hormonal regulation of calcium current in freshly isolated airway smooth muscle cells. Am J Physiol 262:L351L359

Welling A, Bosse E, Ruth P, Bottlender R, Flockerzi V, Hofmann F (1992b) Expression and regulation of cardiac and smooth muscle calcium channels. $\mathbf{J} \mathbf{J}$ Pharmacol 58 Suppl-II 1258p-1262p

Welling A, Bosse E, Cavalie A, Bottlender R, Ludwig A, Nastainczyk W, Flockerzi $\mathrm{V}$, Hofmann F (1993) Stable co-expression of Calcium Channel $\alpha_{1}, \beta$ and $\alpha_{2}, \delta$ Subunits in a Somatic Cell Line. J Physiol, in Press

Williams ME, Feldman DH, McCue AF, Brenner R, Velicelebi G, Ellis SB, Harpold MM (1992a) Structure and functional expression of $\alpha_{1}, \alpha_{2}$, and $\beta$ subunits of a novel human neuronal calcium channel subtype. Neuron 8:71-84

Williams ME, Brust PF, Feldman DH, Patti S, Simerson S, Maroufi A, McCue AF, Velicelebi G, Ellis SB, Harpold MM (1992b) Structure and functional expression of an $\omega$-conotoxin-sensitive human $\mathrm{N}$-type calcium channel. Science 257:389-395 